\title{
Ibogaine modifies GDNF, BDNF and NGF expression in brain regions involved in mesocorticolimbic and nigral dopaminergic circuits
}

\author{
Soledad Marton ${ }^{1 \dagger}$, Bruno González ${ }^{2 \dagger}$, Sebastián Rodríguez ${ }^{1}$, Ernesto Miquel ${ }^{1}$, Laura Martínez \\ Palma $^{1}$, Mariana Pazos ${ }^{2}$, José Pedro Prieto ${ }^{3}$, Paola Rodríguez ${ }^{2}$, Dalibor Sames ${ }^{4}$, Gustavo Seoane ${ }^{2}$, \\ Cecilia Scorza $^{3^{*}}$, Patricia Cassina $^{1^{*}}$, Ignacio Carrera ${ }^{2^{*}}$
}

${ }^{1}$ Departamento de Histología y Embriología, Facultad de Medicina - Universidad de la República, Montevideo Uruguay

${ }^{2}$ Laboratorio de Síntesis Orgánica, Departamento de Química Orgánica, Facultad de Química - Universidad de la República, Montevideo - Uruguay

${ }^{3}$ Departamento de Neurofarmacología Experimental, Instituto de Investigaciones Biológicas Clemente Estable, Montevideo - Uruguay

${ }^{4}$ Department of Chemistry, Columbia University, New York, NY - USA

${ }^{\dagger}$ These authors contributed equally to this work

* Correspondence: Cecilia Scorza (cscorza@iibce.edu.uy), Patricia Cassina (pcassina@fmed.edu.uy), Ignacio Carrera (icarrera@fq.edu.uy)

Keywords: ibogaine, neurotrophic factors, GDNF, BDNF, NGF

\begin{abstract}
Ibogaine is a psychedelic alkaloid which has been subject of intense scientific research due to its reported ability to attenuate drug-seeking behavior. Recent work suggested that ibogaine effects on alcohol self-administration in rats was related to the release of Glial Cell Derived Neurotrophic Factor (GDNF) in the Ventral Tegmental Area (VTA), a mesencephalic region which hosts soma of dopamine neurons. It is well known that neurotrophic factors (NFs) mediate the neuroadaptations induced in the mesocorticolimbic dopaminergic system by repeated exposure to drugs. Although previous reports have shown ibogaine's ability to induce GDNF expression in rat midbrain, there are no studies addressing its effect on the expression of GDNF, Brain Derived Neurotrophic Factor (BDNF) or Nerve Growth Factor (NGF) in distinct regions containing dopaminergic neurons. In this work, we examined the effect of ibogaine acute administration on the expression of these NFs in the VTA, Prefrontal Cortex (PFC), Nucleus Accumbens (NAcc) and the Substantia Nigra (SN). Thus, rats were i.p. treated with ibogaine $20 \mathrm{mg} / \mathrm{kg}\left(\mathrm{I}_{20}\right), 40 \mathrm{mg} / \mathrm{kg}$ ( $\left.\mathrm{I}_{40}\right)$ or vehicle, and NFs expression was analyzed after 3 and 24 hours. Only at $24 \mathrm{~h}$ an increase of the expression for the three NFs were observed in a site and dose dependent manner. Results for GDNF showed that only $\mathrm{I}_{40}$ selectively
\end{abstract}


upregulated its expression in the VTA and SN. Both doses of ibogaine elicited a large increase in the expression of BDNF in the NAcc, SN and PFC, while a significant effect was found in the VTA only for $\mathrm{I}_{40}$. Finally, NGF was found to be upregulated in all regions after $\mathrm{I}_{40}$, while a selective upregulation was found in PFC and VTA for the $I_{20}$ treatment. An increase in the content of mature GDNF was observed in the VTA but no significant increase in the mature BDNF protein content was found in all the studied areas. Interestingly, an increase in the content of proBDNF was detected in the NAcc for both treatments. Further research is needed to understand the neurochemical bases of these changes, and to confirm their contribution to the anti-addictive properties of ibogaine.

\section{Introduction}

Ibogaine is the main indole alkaloid isolated from the root bark of the African shrub Tabernanthe iboga (Lavaud and Massiot, 2017). Traditionally used in African religious ceremonies as a psychedelic, ibogaine became the subject of interest of the scientific community due to its reported ability to reduce craving and self-administration of several drugs of abuse in humans (Brown, 2013). These effects found mainly in uncontrolled clinical trials and observational studies, have been reported to be long-lasting enduring weeks to months after a single administration of large doses of ibogaine (Schenberg et al., 2014; Brown and Alper, 2017; Noller et al., 2017). In animal models for drug dependence, ibogaine also reduces the self-administration of morphine and heroin, (Glick et al., 1991; Glick et al., 1994; Dworkin et al., 1995) cocaine, (Cappendijk and Dzoljic, 1993; Glick et al., 1994) and alcohol, (He et al., 2005) with long-lasting effects that persists beyond pharmacokinetic elimination of the drug (Alper, 2001). In addition, ibogaine administration to animals also reduces naloxone or naltrexone precipitated-withdrawal signs (Dzoljic et al., 1988; Glick et al., 1992; Leal et al., 2003). Several ibogaine effects observed in humans, such as the dissociative or psychedelic effects, (Alper, 2001) tremor induction, (Glick et al., 1994) and prolongation of the $\mathrm{QT}_{\mathrm{C}}$ interval in the EKG (which has been associated with sudden death cases after ibogaine intake), (Koenig and Hilber, 2015), have made it a controversial treatment option and resulted in reluctance to pursue rigorous controlled clinical trials (Brown, 2013). In this regard, unveiling the mechanism of action for ibogaine's anti-addictive property is critical for the development of safer derivatives for clinical use, and for a deeper understanding of the neurobiological basis of substance dependence and its possible treatment.

Although a vast amount of research has been done regarding the pharmacology of ibogaine, the mechanism of action of its anti-addictive effects remains unresolved (Alper, 
2001; Maciulaitis et al., 2008; Brown, 2013). Ibogaine binds to numerous central nervous system (CNS) targets at the micromolar range such as: nicotinic acetylcholine receptors (nAChR $\alpha 3 \beta 4$ and $\alpha 2 \beta 4$ ), N-methyl-D-aspartate (NMDA), kappa and mu opioid, $5 \mathrm{HT}_{2 \mathrm{~A}}$ and $5 \mathrm{HT}_{3}$ receptors and the dopamine and serotonin transporters (Glick et al., 2001). However, these ibogaine-receptor interactions do not seem to account for the long-lasting effects of ibogaine found in rodents which are described to last for 48 to 72 hours after ibogaine administration (Glick et al., 1991; Cappendijk and Dzoljic, 1993; Glick et al., 1994). In rodents, ibogaine has a short half-life of 1-2 hours raising the hypothesis that its longer-lived active metabolite, noribogaine, should be responsible for the enduring effects elicited by ibogaine. However, no appreciable amounts of noribogaine have been found in rodents' brain tissue 19 hours after ibogaine intraperitoneal (i.p.) administration, (Pearl et al., 1997) and only approximately $5 \%$ of the noribogaine Cmax was detected in serum 24 hours after the same treatment (Baumann et al., 2001).

A few years ago, a novel hypothesis linking ibogaine's attenuation of alcohol selfadministration in rodents to its ability to modulate the expression of Glial Cell Derived Neurotrophic Factor (GDNF) in the brain was proposed. It was shown that a single ibogaine i.p. administration $(40 \mathrm{mg} / \mathrm{kg})$ increased the expression of GDNF in the midbrain of rats and mice for up to 24 hours (He et al., 2005). In addition, microinjection of ibogaine into the Ventral Tegmental Area (VTA), produced a long-lasting reduction of ethanol self-administration, a response that was attenuated by the intra-VTA delivery of anti-GDNF neutralizing antibodies. These results suggested that ibogaine mediates its effects against ethanol consumption by increasing GDNF content in the VTA (He et al., 2005). Accordingly, another study from the same research group showed that the intra-VTA infusion of noribogaine induced a long-lasting decrease in ethanol self-administration (Carnicella et al., 2010). Further, ibogaine-derived synthetic derivatives were recently shown to induce the release of GDNF in vitro, in established cell line systems (Gassaway et al., 2016). These observations formed the basis for a new rationale to explain the long-lasting effects of ibogaine; i.e., the induction of GDNF by ibogaine/noribogaine may activate an autocrine loop, leading a long-term synthesis and release of GDNF (that persists beyond elimination of both substances). This mechanism may reverse the biochemical adaptations to chronic exposure to drugs of abuse in the reward system (He and Ron, 2006).

Neurotrophic Factors (NFs), such as GDNF, BDNF (Brain Derived Neurotrophic Factor) or NGF (Nerve Growth Factor) are small proteins that promote the growth, differentiation, synaptogenesis, and survival of neurons. Their expression in the nervous tissue 
is relatively high during the development of the CNS, where substantial growth, differentiation and remodeling of the nervous system occur (Barde, 1990; Lu and Figurov, 1997). More recently, it has been discovered that NFs play important roles in the adult brain where they modulate maintenance, protection, repair and plasticity of the nervous tissue (Reichardt, 2006; Schmidt and Duman, 2007). Furthermore, accumulating evidence has suggested that NFs mediate neuronal remodeling processes that occur during the development of substance use disorders (SUDs) (Bolaños and Nestler, 2004). Particularly, the role of GDNF and BDNF in the neuroadaptations in the mesocorticolimbic dopamine system (Prefrontal Cortex, PFCVTA-Nucleus Accumbens, NAcc pathway) induced by repeated exposure to drugs of abuse has been extensively studied, including the impact of manipulating NFs levels on drug-seeking behavior in animal models (Russo et al., 2009; Ghitza et al., 2010; Koskela et al., 2017). It has been shown that the administration of BDNF or GDNF can either promote or inhibit drugtaking behaviors depending mainly on the brain site of administration, along with other several factors such as the drug type, the addiction phase (initiation, maintenance, abstinence or relapse), the time interval between site-specific NFs injections and the related behavioral assessments (Ghitza et al., 2010). For example, BDNF infusion into the NAcc increases cocaine-seeking behavior, (Graham et al., 2007) while BDNF infusion into the medial prefrontal cortex (mPFC) suppresses it (Berglind et al., 2007). The effect of administrating other NFs (as NGF or Fibroblast Growth Factor, FGF) on drug-seeking behavior and modulation of neuroadaptations produced by chronic administration of drugs of abuse has been less studied. In the case of NGF, for example, it was found that NGF content decreases in the hippocampus and hypothalamus of alcohol-treated mice, (Aloe et al., 1993) and that its administration into the central nucleus of the amygdala mimicked the morphine reward sensitization (Bie et al., 2012). In contrast to BDNF, a single infusion of NGF into the VTA produced no changes in cocaine-seeking behavior (Lu et al., 2004).

Given the importance and the site-specificity of the elicited responses, we decided to analyze the effect of a single administration of ibogaine on the expression of GNDF, BDNF and NGF at two time points, 3 and $24 \mathrm{~h}$ after i.p. injection, in those brain areas which define the mesocorticolimbic dopamine system such as VTA, PFC and NAcc (Figure 1 and 2). As the Substantia Nigra (SN) is a major nucleus of dopaminergic neurons important in the basal ganglia functioning, the expression of these NFs in this region was also studied. In addition, locomotion of control and drug treated animals was recorded using an open field test. 


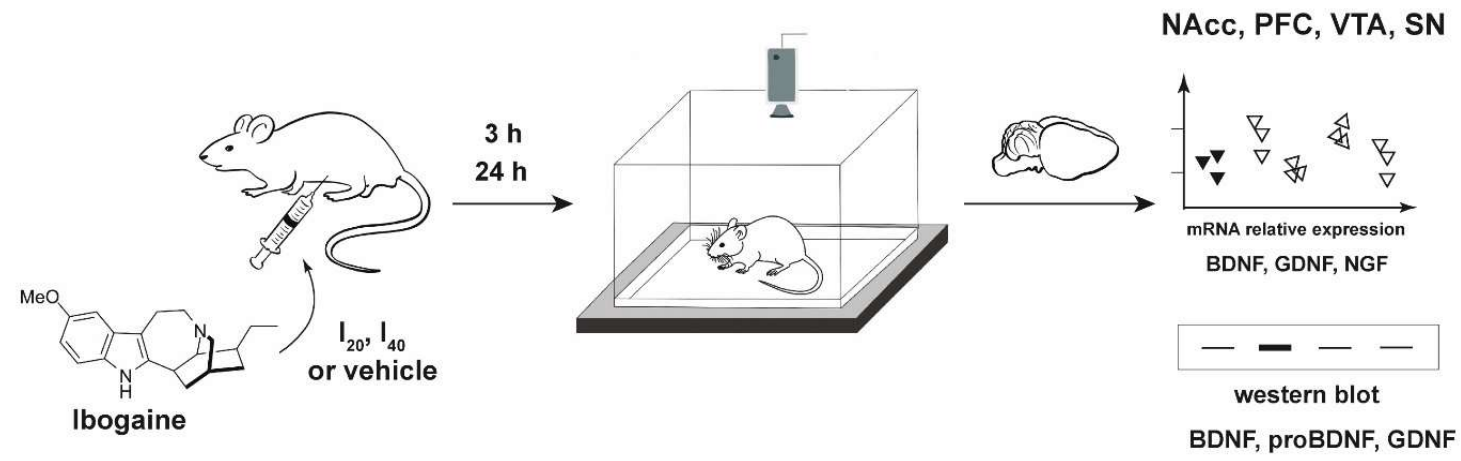

Figure 1. Schematic showing the experimental design of this work. Experimental groups of animals were i.p. treated with ibogaine $20 \mathrm{mg} / \mathrm{kg}$ (I20), $40 \mathrm{mg} / \mathrm{kg}$ (I40) or vehicle. After 3 and 24 hours, locomotion of control and treated animals was recorded using an open field test. Afterwards, animals were sacrificed, and selected brain regions were dissected. mRNA levels for BDNF, GDNF and NGF were determined by qPCR. Western Blot was used to determine BDNF, proBDNF and GDNF protein content. PFC $=$ Prefrontal Cortex, NAcc $=$ Nucleus Accumbens, VTA $=$ Ventral Tegmental Area, and SN $=$ Substantia Nigra, GDNF $=$ Glial Cell Derived Neurotrophic Factor, BDNF $=$ Brain Derived Neurotrophic Factor, NGF = Nerve Growth Factor.

\section{Material and Methods}

\subsection{Ibogaine $\cdot \mathbf{H C l}$}

The ibogaine used in this study was chemically synthesized using voacangine as starting material, which was extracted from the root bark of Voacanga africana using a modification of a previously described procedure (Jenks, 2002). Briefly, 100g of grounded root bark of Voacanga africana was extracted with a $1 \%$ aqueous solution of $\mathrm{HCl}(6 \times 500 \mathrm{~mL})$. The combined aqueous extracts were basified by adding concentrated $\mathrm{NH}_{4} \mathrm{OH}$ until $\mathrm{pH} 10-11$. A brown precipitate was separated by centrifugation and dried at $60^{\circ} \mathrm{C}$ for $24 \mathrm{~h}$. This solid was taken in acetone and filtered to discard root impurities. The solvent was evaporated in vacuo to afford a total alkaloid extract of 3.5-4.0 g. Column chromatography $\left(\mathrm{SiO}_{2}\right.$, Hex:EtOAc: $\left.\mathrm{NH}_{4} \mathrm{OH}, 90: 10: 0.01\right)$ allowed to obtain $1 \mathrm{~g}$ of pure voacangine which was analyzed by ${ }^{1} \mathrm{H}$ and ${ }^{13} \mathrm{C}$ NMR (See supporting information). Voacangine was decarboxylated as follows. To a solution of voacangine in $\mathrm{EtOH}(0.45 \mathrm{M})$ in a double necked round bottomed flask, $\mathrm{KOH}$ in pellets (5 equivalents) was added. The solution was heated to reflux until consumption of the starting material was evident by thin layer chromatography (TLC) analysis. EtOH was removed under reduced pressure, and the residue was dissolved at $0{ }^{\circ} \mathrm{C}$ in a round bottomed flask using a $6 \%(\mathrm{v} / \mathrm{v})$ aqueous solution of $\mathrm{HCl}$ (enough quantity to adjust $\mathrm{pH}$ to 1$)$. The system was then heated to reflux for five minutes. Once the starting material consumption was evident by TLC analysis, the solution was carefully basified using 50\% $\mathrm{NaOH}(\mathrm{pH} \mathrm{10-11).}$ Precipitation of ibogaine as a white solid was observed. Ethyl acetate was added, and the resultant biphasic system was transferred into a separation funnel. The aqueous phase was extracted three times with EtOAc. The combined organic layers were dried under $\mathrm{Na}_{2} \mathrm{SO}_{4}$, and 
the solvent was removed in vacuo. Ibogaine free base was obtained with an $86 \%$ yield and was analyzed by ${ }^{1} \mathrm{H}$ and ${ }^{13} \mathrm{C}$ NMR (see supporting information). Crystallization from EtOH afforded a crystalline solid which was converted to the corresponding hydrochloride by treatment with diethyl ether saturated with $\mathrm{HCl}(\mathrm{g})$. Purity of ibogaine $\cdot \mathrm{HCl}$ was determined by GC-MS analysis as $98.3 \%$ (see supporting information). Dissolution of ibogaine-HCl to prepare the samples for i.p. injection was carried out using warm saline that was previously degassed by nitrogen bubbling.

\subsection{Experimental Animals}

Thirty-six Wistar adult rats (270-300 g) were used in this study and assigned to one of the following groups: Vehicle group at 3 and $24 \mathrm{~h}$ ( $\mathrm{n}=6$ per each group); Ibogaine $20-\left(\mathrm{I}_{20}\right)$ treated group at $3 \mathrm{~h}$ and $24 \mathrm{~h}\left(\mathrm{n}=6\right.$ per each group) and Ibogaine $40-\left(\mathrm{I}_{40}\right)$ treated group at 3 and $24 \mathrm{~h}$ ( $\mathrm{n}=6$ per each group). Animals were housed four to five per cage and maintained on a 12-h light/dark cycle (lights on at $07.00 \mathrm{~h}$ ) with food and water freely available before and after i.p. injection of vehicle or ibogaine until behavioral testing and sacrifice. All experimental procedures were conducted in agreement with the National Animal Care Law (\#18611) and with the "Guide to the care and use of laboratory animals" (8th edition, National Academy Press, Washington D. C., 2010). Furthermore, the Institutional Animal Care Committee approved the experimental procedures. Adequate measures were taken to minimize pain, discomfort or stress of the animals, and all efforts were made to use the minimal number of animals necessary to obtain reliable scientific data.

\subsubsection{Behavioral analysis}

Animals were brought to the experimental room in their home cages, identified and weighed prior to the behavioral test. An open field (OF) apparatus consisting of a square area $(45 \mathrm{~cm}$ wide $\times 45 \mathrm{~cm}$ long $\times 40 \mathrm{~cm}$ high) with transparent plastic walls indirectly illuminated (35 luxes) to avoid reflection and shadows were employed. The OF was placed in a quiet experimental room with controlled temperature $\left(22 \pm 2{ }^{\circ} \mathrm{C}\right)$. As rats were not habituated to the OF before drug or vehicle administration, novelty-induced motor activity was automatically recorded by a camera connected to a computer equipped with the Ethovision XT 12.0 software (Noldus, Netherlands) located above the OF. Using this video tracking software, we specifically measured the total distance traveled in meters (m) during $30 \mathrm{~min}$, starting 3 and $24 \mathrm{~h}$ after ibogaine or vehicle administration. Animals were randomly assigned to different experimental groups and were used only once. Taking into account that immediately after i.p. administration 
ibogaine can produce a dose-dependent unusual motor profile and some prototypical serotonergic syndrome-related behaviors (e.g., tremor, flat body posture, forepaw treading) (Gonzalez et al. 2018), these specific behaviors were assessed by a trained investigator every $5 \mathrm{~min}$ (for a total of $30 \mathrm{~min}$ ) starting 3 and $24 \mathrm{~h}$ after ibogaine administration. During all experiments, the OF was cleaned with $30 \%$ alcohol before placing the following rat. All experiments were done between 9 AM and 3 PM.

\subsection{Ex Vivo Studies}

\subsubsection{Brain dissection}

Three or twenty-four hours after $\mathrm{I}_{20}, \mathrm{I}_{40}$ or vehicle (i.p.) injection, animals were sacrificed by decapitation and the brains were carefully removed and chilled in ice cold saline. According to Paxinos and Watson (Paxinos and Watson, 2005), the whole NAcc (shell and core), PFC (including mPFC), Substantia Nigra (SN, pars compacta-SNpc and pars reticulataSNpr) and VTA were dissected out on ice and the tissue obtained was immediately frozen and rapidly stored at $-80{ }^{\circ} \mathrm{C}$ until the processing day (Scorza et al., 1997; Meikle et al., 2013). Representative examples of coronal section at the level of each dissected brain area are shown in Figure 2.

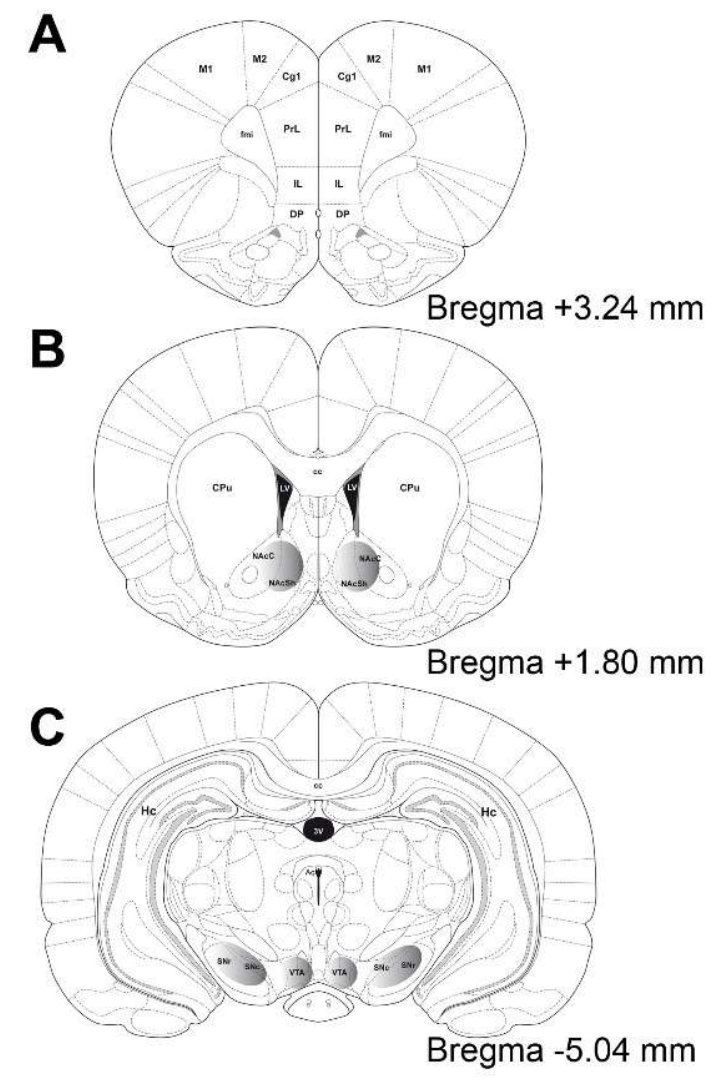

Figure 2. Dissected brain areas. Figure shows a schematic diagram of coronal sections at three different levels. A: +3.24 for PFC, B: +1.80 for NAcc, and C: -5.04 for VTA and SN, from Bregma) according to Paxinos and Watson (2005) atlas. In A, a complete slice ( $2 \mathrm{~mm}$ ) was taken for PFC (including the $\mathrm{mPFC}$ ). In $\mathrm{B}$ and $\mathrm{C}$, gray areas indicate an approximately extension of the brain tissue dissected for NAcc ((this region was punched by using a sample corer with an inner diameter of $2 \mathrm{~mm}$ ), VTA and SN, respectively. Cg, cingulate cortex; PrL, prelimbic; IL, infralimbic; M1 and $\mathrm{M} 2$, motor cortex; $\mathrm{CPu}$, corpus striatum; $\mathrm{NAcC}$ and NAcSh, nucleus accumbens core and shell; Hc, hippocampus; $\mathrm{CC}$, corpus callosum; $3 \mathrm{~V}$, third ventricle, SNc and SNr, compact and reticular subtantia nigra; VTA, ventral tegmental area. 


\subsubsection{Semiquantitative qPCR}

For RT-PCR analysis total RNA was extracted from the different brain regions using Trizol reagent (ThermoFisher Scientific) followed by chloroform extraction and isopropanol precipitation. Possible DNA contaminations were eliminated with DNase treatment using DNase free Kit (Thermo Fisher Scientific). RNA quality was evaluated by agarose gel electrophoresis followed by ethidium bromide staining and quantified using a NanoDrop 1000 Spectrophotometer (Thermo Fisher Scientific). $500 \mathrm{ng}$ of this total RNA was reversetranscribed using 200 U M-MLV-reverse transcriptase (Thermo Fisher Scientific) following manufacturer instructions. $25 \mathrm{ng}$ of the resulting cDNA was diluted in Biotools Quantimix Easy master mix (Biotools) in $10 \mu$ volume. All reactions were performed in triplicates in strip tubes (Axygen ${ }^{\circledR}$ Brand Products), using specific forward and reverse primers. The sequences of the quantitative PCR primers (IDT, Integrated DNA Technologies) used are as follows: for GAPDH F: 5'- CAC TGA GCA TCT CCC TCA CAA - 3' and R: 5'- TGG TAT TCG AGA GAA GGG AGG - 3', for BDNF F: 5'- GAG GGG TAG ATT TCT GTT TGT T -3' and R: 5'- TTG CCT TAA TTT TTA TTC GTT T -3', for GDNF F: 5' - AAA TCG GGG GTG CGT CTT AAC T -3' and R: 5'- AAC ATG GGC CTA CCT TGT C -3', for NGF F: 5'- AAG TTA TCC CAG CCA AAC TA -3' and R: 5'- ATG TCA GTG TTG GGA GTA GG -3'. PCR amplification was done over 40 cycles using a Rotor-Gene 6000 System (Corbett Life Science) and data were analyzed using Rotor Gene 6000 software (Corbett Life Science). Quantification was performed with $\Delta \Delta \mathrm{Ct}$ method using rats treated with vehicle as a negative control, and GAPDH mRNA as reference.

\subsubsection{Western Blot analysis}

The selected brain regions were sonicated in a lysis buffer containing $50 \mathrm{mM} \mathrm{NaCl}, 50 \mathrm{mM}$ HEPES, 2 mM sodium orthovanadate, 1\% Triton X-100, and SigmaFAST Protease inhibitor cocktail (Sigma-Aldrich). After quantification and denaturation, the samples were loaded and separated by $12 \%$ SDS-PAGE gels and then transferred into a nitrocellulose membrane. The membranes were incubated for $1 \mathrm{~h}$ in blocking solution (BS: 5\% Bovine serum albumin, 1\% Tween 20 in PBS), and incubated overnight at $4{ }^{\circ} \mathrm{C}$ with primary antibodies to GDNF (1:500 in BS; Abcam ab119473), BDNF (1:400 in BS; Promega G1641), or proBDNF (1:500 in BS; Invitrogen PA1-18360), together with anti-alpha-tubulin (1:3000 in BS; Abcam ab184613) as

loading control. Afterwards, the membranes were washed and incubated for 1 hour at room temperature with IRDye 680RD/ IRDye 800CW-Conjugated Goat Anti-Mouse IgG/ Goat Anti-Rabbit IgG/ Donkey Anti-Chicken IgG secondary antibodies (1:15000 in PBS each, LI- 
COR Biosciences \#926-68070, \#926-32210, \#926-68071, \#926-32211, and \#925-32218). The Odyssey system (LI-COR Biosciences) was used to detect the bands. Quantification of band intensity was performed using Image Studio software version 5.2.5.

\subsection{Data analysis}

GraphPad Prism software 5 was used to design figure graphs and data analysis. Data are presented as mean \pm S.E.M values. Six animals per group were assessed for comportamental and PCR studies. In some cases, some data was excluded from the analysis due to insufficient sample or high deviation from the mean of the group, rendering a lower $\mathrm{n}$, but never smaller than 4 . The total sample size $(N)$ is given in figure legends and the sample for each treatment $(n)$ can be observed in the scatter plot graphs in each figure. For western blot analysis, samples from 4 animals per group were assessed. Data from qPCR and western blot were analyzed and compared by one-way ANOVA followed by post hoc Tukey's Multiple Comparison Test. In all cases, statistical significance was set at $\mathrm{p}<0.05$. General $P$ and $F$ values from ANOVA, and $p$ values from Tukey's multiple comparison test are provided in figure legends for each data set when significance is reached. Data from motor activity were analyzed by two-way (treatment, time, and interaction between factors) ANOVA for repeated measures followed by Newman-Keuls multiple comparison post hoc test and Unpaired-t-test. In all cases, statistical significance was set at $p<0.05$.

\subsection{Results}

In a previous study, we reported a very high impact of the $\mathrm{I}_{40}$ treatment on noveltyinduced locomotion after two hours of ibogaine administration and the concomitant induction of some of the behavioral signs related to the serotonergic syndrome (Gonzalez et al., 2018). Thus, we decided to analyze the behavioral effect of ibogaine treatment in the time points used in the present study. The behavioral response induced by ibogaine is shown in Figure 3. Compared to the control group, novelty-induced locomotion was not altered by $\mathrm{I}_{20}$ at any evaluated time (data not shown). Whereas $\mathrm{I}_{40}$ was not effective to induce any behavioral alterations $3 \mathrm{~h}$ after i.p. administration, it elicited a significantly reduction of the animal locomotion $24 \mathrm{~h}$ after injection (Fig. $3 \mathrm{~A}$ and B, respectively). No abnormal behaviors were present for both time points and animals were qualitatively indistinguishable from the vehicle group animals (data not shown). Immediately after each behavioral test, animals were sacrificed to pursue brain dissection for the qPCR and Western Blot studies. 


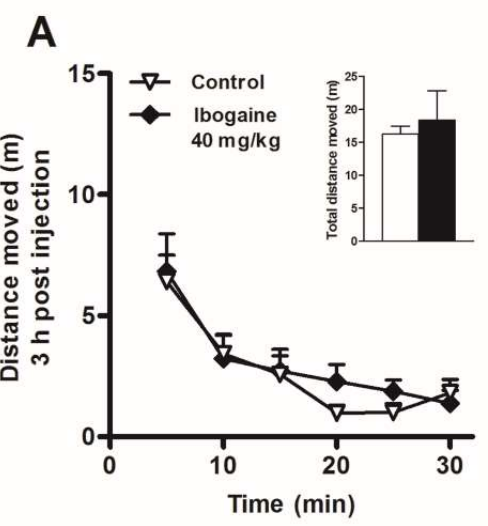

Figure 3. Effects of ibogaine administration on locomotor activity. Locomotor activity of rats was recorded in the OF test during $30 \mathrm{~min}$, at $3 \mathrm{~h}$ (A) and $24 \mathrm{~h}$ (B) after ibogaine $(40 \mathrm{mg} / \mathrm{kg})$ i.p. administration. The inset graphs represent the total locomotor activity $(30 \mathrm{~min})$. Data are expressed as mean + SEM. Data were analyzed by the two-way ANOVA of repeated measured followed by Newman-Keuls test and Unpaired $t$-test (insets). For 24 $\mathrm{h}$ after treatment, two-way ANOVA revealed a significant effect of the treatment $F_{(1,8)}=11.14, P<.01$, time $F_{(5,40)}=66.56, P<.001$, and treatment $\mathrm{x}$ time interaction $F_{(5,40)}=4.85, P<.01$. ${ }^{*}$, respective to saline group. $* * * p<$

B $.001 ; * * p<.01 ; * p<.05 . N=18, n=6$ per group.

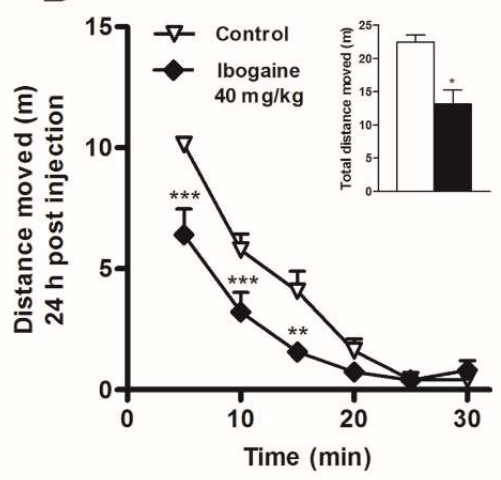

\section{1 qPCR quantification of NFs mRNA}

qPCR results for the GDNF (Figure 4) showed that ibogaine acute administration differentially regulated GDNF mRNA expression levels in the selected brain regions in a dose and time-dependent manner. At 3 hours, no changes in the GDNF mRNA expression was found for both doses of ibogaine in all the studied areas. In contrast, after 24 hours of treatment, changes in the expression of GDNF were found in a dose and site-specific manner. While the $\mathrm{I}_{20}$ dose did not affect the GDNF expression in any of the studied areas, the $\mathrm{I}_{40}$ dose selectively increased GDNF mRNA content in the midbrain regions: VTA (12-fold increase compared to the control group) and SN (6-fold increase vs the control group) with no appreciable effects in the PFC and NAcc. 


\section{GDNF transcript}

PFC
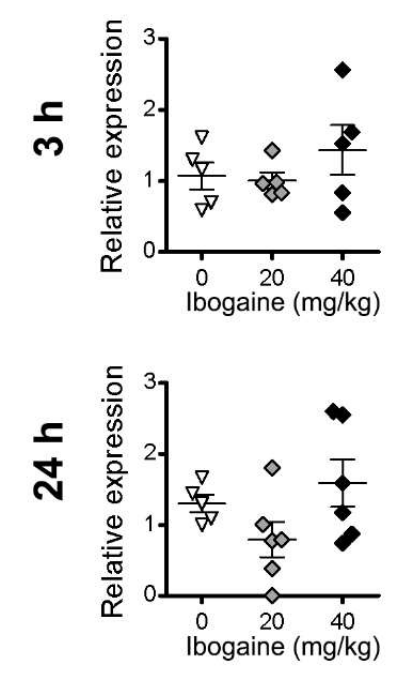

NAcc
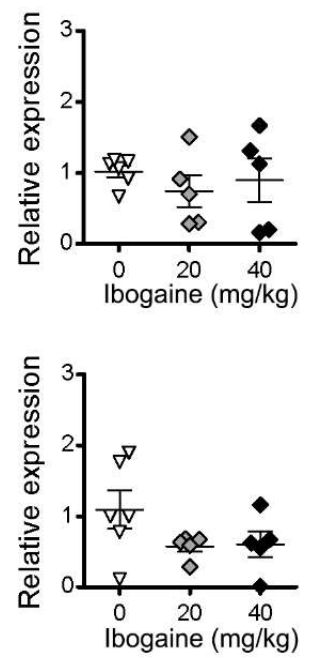

VTA
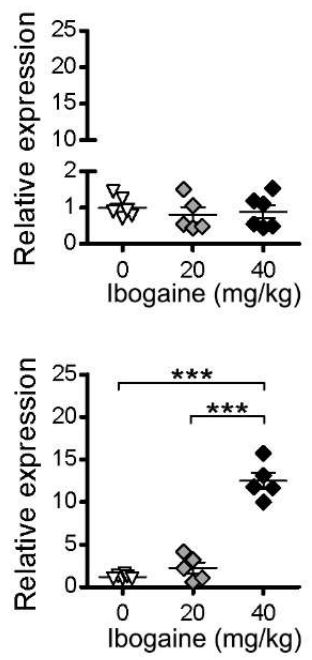

SN
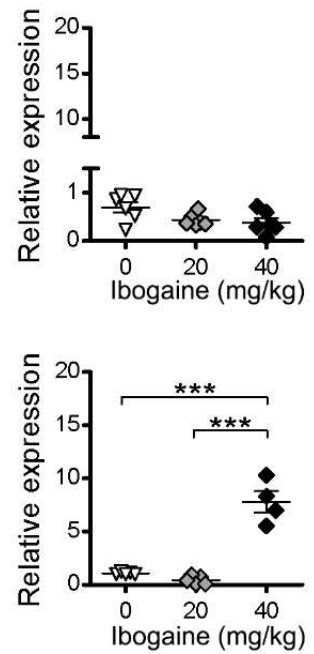

Figure 4. Effects of ibogaine administration on GDNF expression in specific brain areas. Quantitative analysis of GDNF transcript levels in the indicated brain areas after 3 hours (upper panels) or 24 hours (lower panels) of vehicle (0), 20 or $40 \mathrm{mg} / \mathrm{kg}$ ibogaine administration. For $24 \mathrm{~h}$ after treatment VTA, $N=16, P<.0001, F_{2,13}=96.11$; For $24 \mathrm{~h}$ after treatment $\mathrm{SN}, N=14, P<.0001, F_{2,11}=60.75 ; * * * p<.001$ between indicated groups.

For BDNF, ibogaine treatment produced an appreciable downregulation of its expression in the PFC at 3 hours after injection (1.7 and 2-fold decrease for $\mathrm{I}_{20}$ and $\mathrm{I}_{40}$ respectively, compared to control), while no response was seen for the other brain areas at this time point (Figure 5). At 24 hours, ibogaine administration upregulated the mRNA expression of BDNF in all the brain regions studied in a dose-dependent manner (Figure 5). A large effect was found in the NAcc for both doses of ibogaine (220-fold increase compared to the control for $\mathrm{I}_{20}$, and 340-fold increase for $\mathrm{I}_{40}$ ). The $\mathrm{I}_{20}$ dose increased BDNF expression in PFC (55-fold increase compared to the control) but not in the VTA or SN. On the other hand, in addition to the NAcc, the $\mathrm{I}_{40}$ dose also upregulated BDNF expression in PFC (107-fold increase compared to the control), VTA (43-fold increase compared to the control) and SN (21-fold increase compared to the control). 


\section{BDNF transcript}

PFC
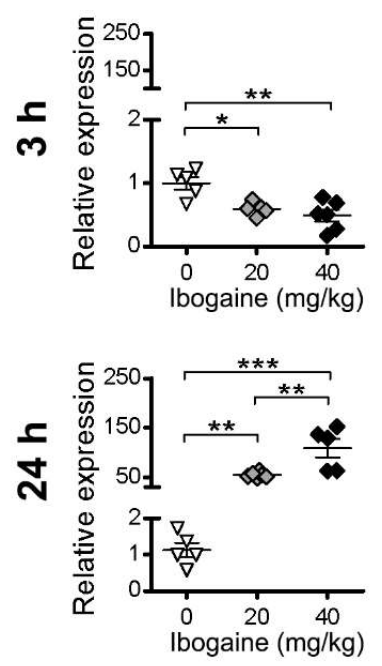

NAcc
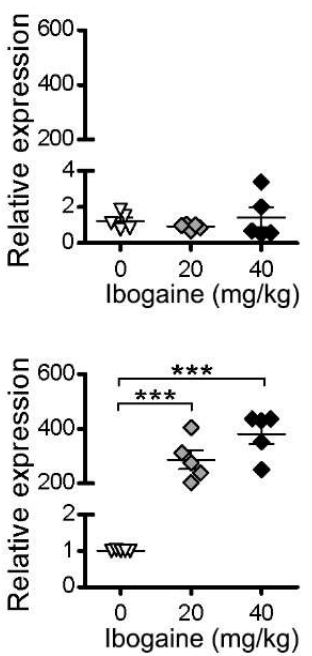

VTA
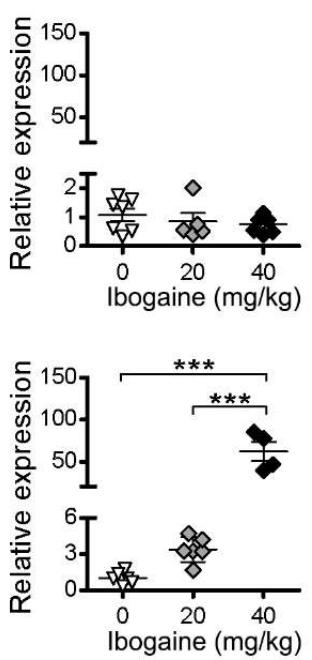

SN
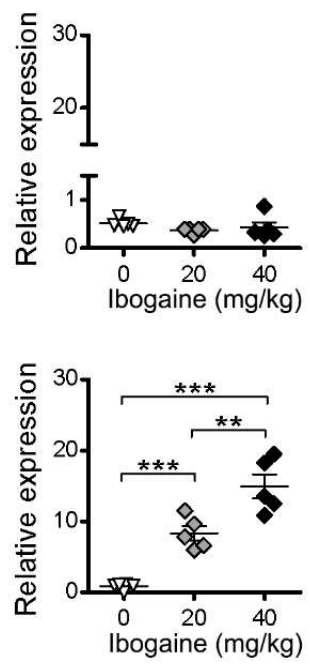

Figure 5. Effects of ibogaine administration on BDNF expression in specific brain areas. Quantitative analysis of BDNF transcript levels in the indicated brain areas after 3 hours (upper panels) or 24 hours (lower panels) of vehicle (0), $20 \mathrm{or} 40 \mathrm{mg} / \mathrm{kg}$ ibogaine administration. For $3 \mathrm{~h}$ after treatment $\mathrm{PFC}, N=16, P<.0001, F_{2,13}=9.80$; For $24 \mathrm{~h}$ after treatment $\mathrm{PFC}, N=16, \mathrm{P}<.0001, F_{2,13}=25.26$; For $24 \mathrm{~h}$ after treatment NAcc, $N=15, P<.0001, F_{2,12}=46.62$; For $24 \mathrm{~h}$ after treatment VTA, $N=14, \mathrm{P}<.0001, \mathrm{~F}_{2,11}=46.46$; For $24 \mathrm{~h}$ after treatment $\mathrm{SN}, N=16$, $\mathrm{P}<.0001, F_{2,13}=45.50 ; * p<.05, * * p<.01$ and $* * * p<.001$ between indicated groups.

For NGF (Figure 6), no difference in the content of mRNA was found 3 hours after ibogaine treatments. At 24 hours, an upregulation of NGF mRNA content was found in: PFC (14-fold increase compared to the control), NAcc, (15-fold increase compared to the control), VTA (11-fold increase compared to the control), and SN (4-fold increase compared to the control). For the $\mathrm{I}_{20}$ dose a significant effect was only found in the PFC (7-fold increase compared to the control) and VTA (5-fold increase compared to the control). However, the levels of increase in the NGF mRNA were not as high as those for BDNF. 


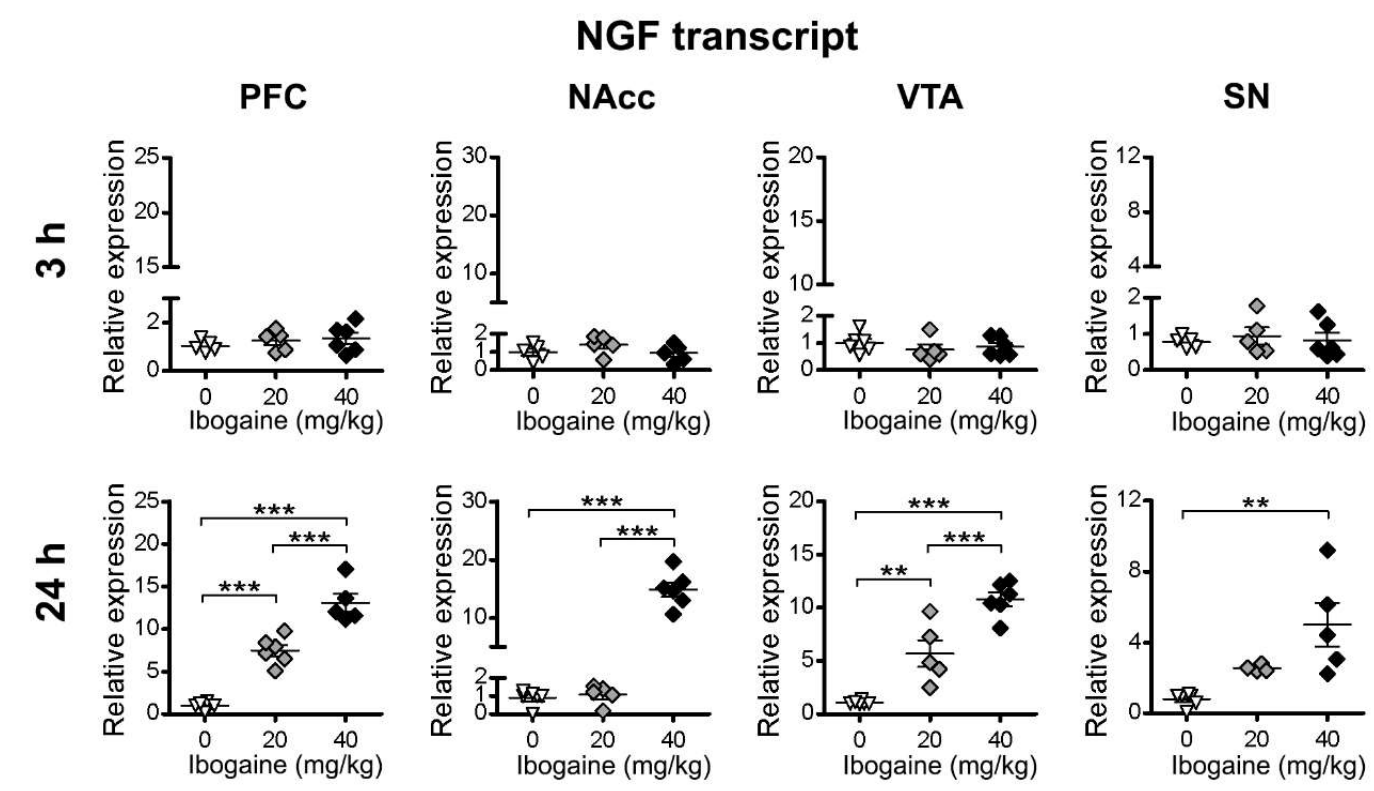

Figure 6. Effects of ibogaine administration on NGF expression in specific brain areas. Quantitative analysis of NGF transcript levels in the indicated brain areas after 3 hours (upper panels) or 24 hours (lower panels) of vehicle (0), 20 or $40 \mathrm{mg} / \mathrm{kg}$ ibogaine administration. For $24 \mathrm{~h}$ after treatment PFC, $N=17, P<.0001, F_{2,14}=76.40$; For $24 \mathrm{~h}$ after treatment NAcc, $N=17, P<.0001, F_{2,14}=107.1 ;$ For $24 \mathrm{~h}$ after treatment VTA, $N=17, P<.0001, F_{2,14}=44.88$; For $24 \mathrm{~h}$ after treatment $\mathrm{SN}, N=16, P=.0050, F_{2,13}=8.16 ; * * p<.01$ and $* * * p<$ .001 between indicated groups.

\subsection{GDNF, BDNF and proBDNF protein content by Western Blot}

Considering the changes found for the expression of NFs after 24 hours of ibogaine administration, we decided to analyze the content of mature proteins BDNF and GDNF for all the studied brain regions, because of their involvement in the addictive behavior. Precursor of BDNF, proBDNF was also considered since it is well described that it shows opposite effects to the mature protein because of a higher affinity to the p75 receptor (Woo et al., 2005; Xu et al., 2011; Sun et al., 2012). For GDNF, a single dose of ibogaine affected mature protein content in a region- and dose-dependent manner (Figure 7). While no changes in GDNF content were observed for $\mathrm{I}_{20}$ in any of the studied regions, GDNF content was increased in VTA for the $\mathrm{I}_{40}$ dose (2-fold increase compared to the control group). No effect was observed in the GDNF content at the NAcc, SN and PFC in comparison to the control group. For BDNF no significant change in the mature protein content was detected for all the studied regions for both doses of ibogaine. Nevertheless, in the case of proBDNF we found a selective increase in the protein content for $\mathrm{I}_{20}$ and $\mathrm{I}_{40}$ in the NAcc (2.7 and 2.8-fold increase for $\mathrm{I}_{20}$ and $\mathrm{I}_{40}$ doses respectively, compared to control), while no significant change was detected in the other brain areas. 

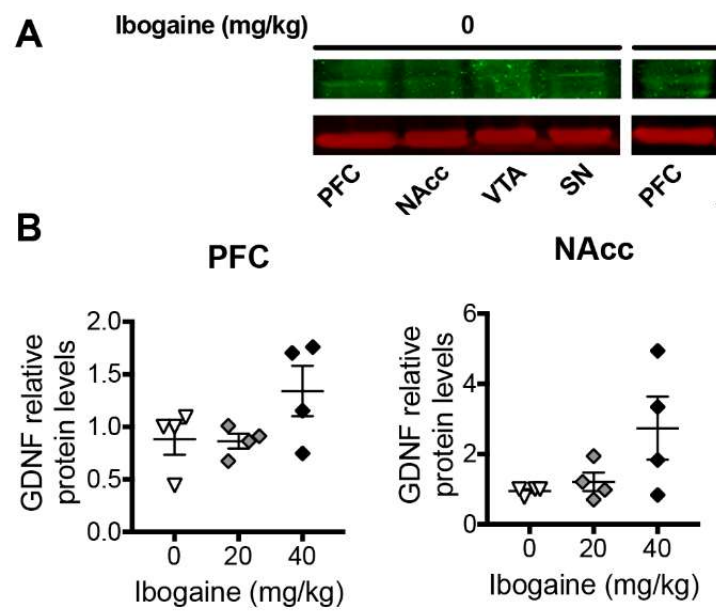

20

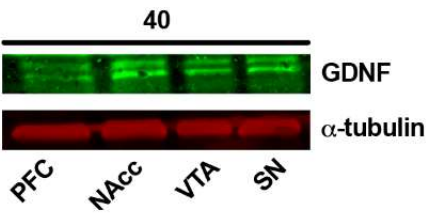

VTA

SN

C

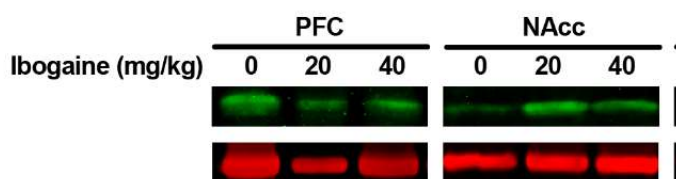

PFC

NAcc
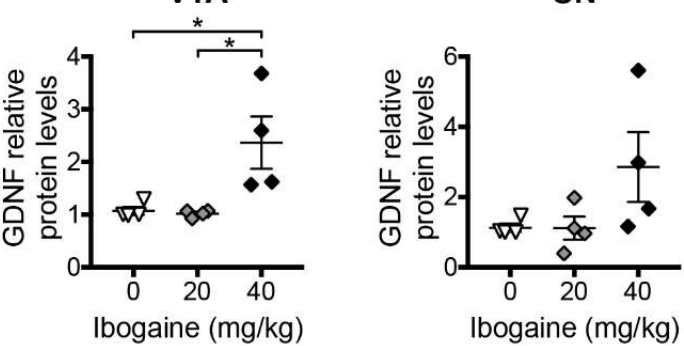

Ibogaine $(\mathrm{mg} / \mathrm{kg}$ )

D
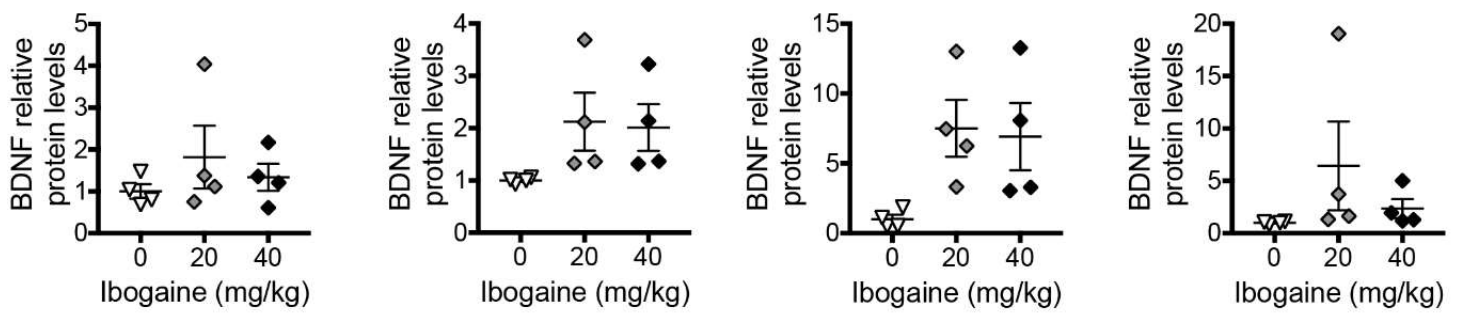

E

PFC

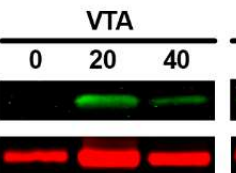

\begin{tabular}{lll}
\multicolumn{3}{c}{ SN } \\
\hline 0 & 20 & 40
\end{tabular}

$\square$ BDNF

$\alpha$-tubulin

VTA

SN
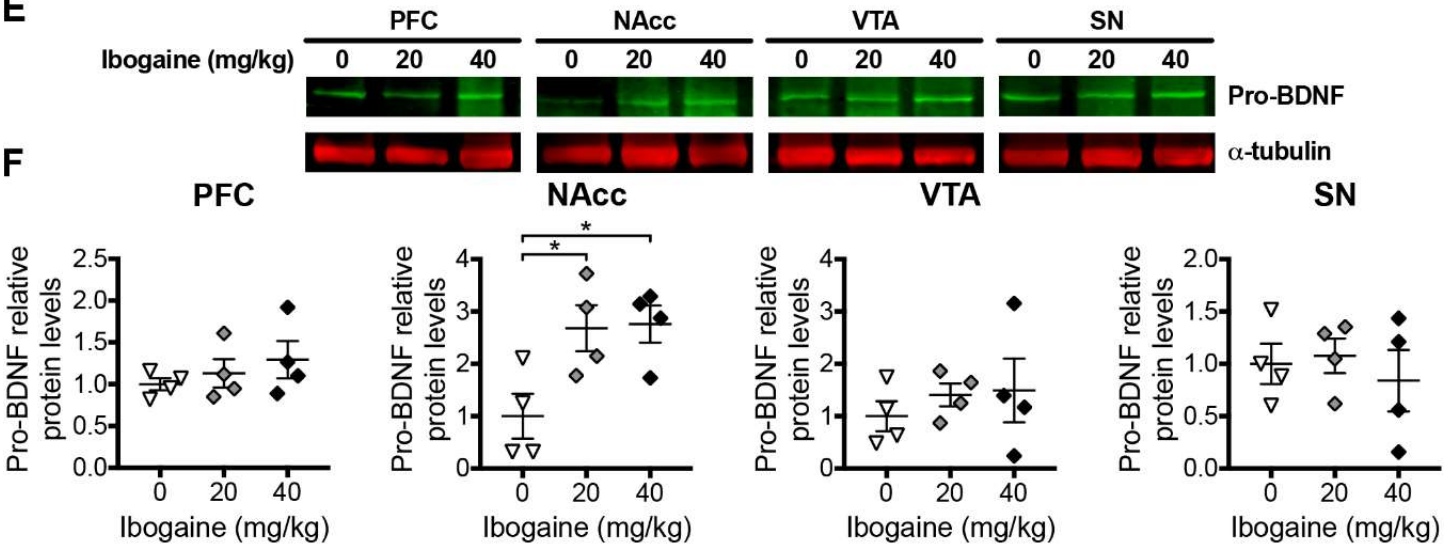

Figure 7. Effects of ibogaine administration on GDNF, BDNF and proBDNF protein levels in specific brain areas. Western blot analysis of GDNF (A-B), BDNF (C-D) and proBDNF (E-F) protein levels in the indicated brain areas after 24 hours of vehicle (0), 20, or $40 \mathrm{mg} / \mathrm{kg}$ ibogaine administration. A representative image from immunostained membrane of each condition is shown $(\mathrm{A}, \mathrm{C}, \mathrm{E})$ with the corresponding quantification below (B, D, F). Data represent mean \pm SEM of $n=4$ biological replicates assayed in triplicate. For GDNF/VTA, $N=12, P<$ $.05, F_{2,9}=6.86$; For proBDNF/NAcc, $N=12, P<.05, F_{2,9}=5.87 ; * p<.05$ between indicated groups. 


\subsection{Discussion}

In the present study, we have demonstrated that ibogaine administration simultaneously alters the expression of the two main trophic factors involved in addictive behavior: GDNF and BDNF, but also NGF in rat brain regions related to the dopamine neurotransmission in a dose and time dependent manner. In addition, we showed that after 24 $\mathrm{h}$ of treatment, I40 selectively increased the content of mature GDNF in the VTA, while proBDNF content was increased selectively in NAcc by both doses. Considering that dopamine neurotransmission, specifically in the mesocorticolimbic pathway, is related to rewarding/reinforcing and motivational actions of most drugs of abuse (Di Chiara and Imperato, 1988; Koob and Bloom, 1988; Kalivas and Volkow, 2005) our findings contribute to shed light on a mechanism underlying the anti-addictive action of ibogaine. According to previous pharmacokinetics reports in rats using i.p. administration (Baumann et al., 2001), ibogaine concentration in blood rapidly decreases in the first hour while noribogaine concentration is at maximum at $2.4 \mathrm{~h}$ and lasts up to $24 \mathrm{~h}$. Regarding concentrations in the brain, no appreciable amounts of noribogaine have been found in the brain tissue of rodents 19 $\mathrm{h}$ after ibogaine i.p. administration (Pearl et al., 1997). Given these previous reports, we chose to study NFs expression/content in the selected brain areas at $3 \mathrm{~h}$, where the parent drug and its metabolite are present in relevant concentrations, and at $24 \mathrm{~h}$ where both drugs are no longer detectable in the brain. In this manner, the observed effects found at $24 \mathrm{~h}$ involving NFs expression and the outcome of the locomotion study, would be due to signaling mechanisms elicited by the drug which remain after it has been cleared from the brain, and not from the acute effects of ibogaine/noribogaine. These results may provide the rationale for the previously reported long-lasting anti-addictive effects of ibogaine (Brown, 2013).

Regarding the motor function, a decrease in the novelty-related motor activity was observed $24 \mathrm{~h}$ after $\mathrm{I}_{40}$ (while $3 \mathrm{~h}$ after the same treatment, animals displayed a similar activity than the control). There is no evidence at this point to establish a potential connection between this intriguing behavior and the observed changes in NFs expression. In this regard, considering the changes in the expression of NFs at $24 \mathrm{~h}$ in the $\mathrm{SN}$, it is plausible that a neurochemical imbalance in the basal ganglia output may underlie the changes in the motor activity (Day et al., 2008; Calabresi et al., 2014). Also, since the induced increase of GDNF content in the VTA by ibogaine has been proposed previously as a putative mechanism to reduce motivational behaviors in alcohol self-administration paradigms (Carnicella et al. 2009; 2010; He et al. 2005), we cannot rule out that this acute motor impairment is related to this neurochemical effect eliciting a decrease in the animal overall motivation. In order to address this hypothesis, 
another experimental design would be needed, including specific behavioral paradigms. Further studies should also include the relationship between changes in the expression of NFs and other factors which may be altered in ibogaine-treated animals at this time point.

At $3 \mathrm{~h}$ after $\mathrm{I}_{20}$ and $\mathrm{I}_{40}$ treatments, no alteration of GDNF expression was found in all the studied brain areas. This is in contrast with previous work reported by He et al. (2005), where a significant GDNF upregulation was found $3 \mathrm{~h}$ after $\mathrm{I}_{40}$ treatment in the midbrain of rats. Differences between both reports may rely in the analyzed brain regions. We studied the effect of ibogaine administration on GDNF expression in specific brain areas (PFC, VTA, NAcc and $\mathrm{SN}$ ), while the whole midbrain was used in the study by He et al. On the other hand, after $24 \mathrm{~h}$, we found that the $\mathrm{I}_{40}$ dose increases GDNF expression and mature protein content specifically in the rat VTA, which was also found in the whole midbrain at this time point in the mentioned previous report. In this manner our study identifies the VTA as the key brain region of the mesocorticolimbic system where GDNF is upregulated after $24 \mathrm{~h}$ of ibogaine administration. This finding is important since the ability of ibogaine to attenuate ethanol selfadministration had previously been proposed to be mediated, at least in part, by the increase in GDNF content in the VTA. (He et al., 2005; He and Ron, 2006) Furthermore, we show that $\mathrm{I}_{20}$ administration does not increase GDNF expression in any of the studied brain areas, which is in accordance with the observation that this dose was not effective in reducing drug selfadministration in the majority of previous studies in rodents (Glick et al., 1991; Cappendijk and Dzoljic, 1993; Glick et al., 1994; Dworkin et al., 1995). In addition, our results are in line with the reports indicating that GDNF infusions into the VTA has been effective in reducing drug self-administration or conditioned place preference in rodents (for cocaine and alcohol) (Messer et al., 2000; He and Ron, 2006; Carnicella et al., 2008; Carnicella et al., 2009), and with the proposal that upregulation of the GDNF pathway represents a potential strategy to treating SUDs (Carnicella and Ron, 2009). Lastly, I 40 administration increases GDNF expression in the SN, which was not accompanied with a significant increase of the GDNF protein content at this time point.

Since in this study the mRNA content was analyzed in whole tissue from the different regions, the precise cell source of GDNF was not identified. Literature indicates that GDNF may be produced either by neuronal or glial cells (Schaar et al., 1993; Moretto et al., 1996; Pochon et al., 1997). Ibogaine treatment upregulated GDNF secretion in dopaminergic neuronlike SHSY5Y cells in culture, (He and Ron, 2006) however since astrocytes are a major source of NFs (Moretto et al., 1996) the glial origin cannot be excluded. This observation deserves further attention, since an increase in GDNF in different cell types in regions containing 
dopaminergic neurons by ibogaine/noribogaine administration could be important for future development of therapeutics for neurodegenerative disorders.

With regard to BDNF, a selective downregulation of its expression in the PFC for both doses of ibogaine was found after $3 \mathrm{~h}$ of administration, while no changes in other areas were observed. Ibogaine and noribogaine administration in rats stimulate the secretion of corticosterone, being ibogaine a more potent releaser (Baumann et al., 2001). Since corticosterone decreases BDNF expression in the frontal cortex (Dwivedi et al., 2006; Huang et al., 2011), ibogaine induced corticosterone secretion during the first hours after treatment (where ibogaine concentrations in blood are high), could be the reason behind this result. In contrast, at $24 \mathrm{~h}$, an impressive upregulation of BDNF expression was found, which was much more pronounced compared to the effect on GDNF and NGF expression in all the studied brain areas at this time point. Nevertheless, this high effect on BDNF expression was not reflected on an increase in the content of BDNF mature protein, since no significant differences were found between both treatments and the control group at this time point, although trending toward increased BDNF protein levels in NAcc and VTA for both doses (Figure 7). Since BDNF is synthesized in a precursor form, we included proBDNF in our experimental design. A selective increase in the proBDNF content was selectively found for NAcc for both ibogaine doses. It is known that the mature BDNF protein and its precursor proBDNF have opposite effects on neuronal protection, axonal growth, maturation of dendrites and synaptic plasticity, owing to different affinities of each form to the TrkB and p75 receptors.(Xu et al., 2011; Benarroch, 2015; Borodinova and Salozhin, 2016). These opposite effects have been hypothesized specifically in the NAcc in the context of animal models of depression as learned helplessness and social defeat stress, where BDNF content is increased while proBDNF content is decreased compared to control animals in this brain area (Shirayama et al., 2015; Yang et al., 2016; Montagud-Romero et al., 2017). In this regard, since it is well-documented that an increase in BDNF content in the NAcc increases cocaine-seeking behavior (Graham et al., 2007) and vulnerability to substance abuse (Krishnan et al., 2007; Burke and Miczek, 2015), an increase in proBDNF in this brain area could have an opposite impact. In this line of reasoning, the increase in proBDNF content in NAcc generated by ibogaine after $24 \mathrm{~h}$ of administration in rats, could also be implicated in ibogaine's effect in drug self-administration paradigms. Further experiments are required to address this hypothesis.

Despite implicit assumption that differentially expressed mRNAs are reflected in protein content, numerous previous studies comparing mRNA and protein levels concluded that the correlation is poor (de Sousa Abreu et al., 2009; Maier et al., 2009). While the increase 
in GDNF mRNA expression was linked to augmented mature protein content, our data showing an impressive increase in BDNF mRNA expression and no changes in mature protein are intriguing. The possibility exists that the time frame of protein synthesis is different for both NFs, however many other factors should be considered to explain this incongruousness. These include post-transcriptional regulation, for example miRNA-based translation repression or alternative splicing, or translational and post-translational modifications. Indeed, it has been previously described that sortilin, an intracellular chaperon, acts as a regulatory switch for delivery of BDNF to the regulatory secretory pathway or to degradation in the lysosome, modulating in this way the neurotrophic factor availability (Evans et al., 2011). Interestingly, BDNF levels have been shown to be modified in PFC after chronic ethanol exposure (Yang et al., 2017).

How does ibogaine administration produce this long-term upregulation of GDNF and BDNF? It is well established that an increase in serotonin transmission leads to an increase in BDNF expression/signaling both in vitro and in vivo (Rantamaki et al., 2007; Popova et al., 2017). In addition, serotonin and SSRIs (Selective Serotonin Re-uptake Inhibitors) induce GDNF expression in vitro (Hisaoka et al., 2001; Mercier et al., 2004; Tsuchioka et al., 2008; Golan et al., 2011), and recently it has been shown that chronic treatment in mice using SSRIs induce GDNF content in SN and Striatum (Shadfar et al., 2018). It is well-established that ibogaine and noribogaine increase serotonin transmission (Wei et al., 1998; Wells et al., 1999; Baumann et al., 2001). Both substances are serotonin-reuptake inhibitors (Jacobs et al., 2007; Bulling et al., 2012), and noribogaine is more potent at increasing serotonin levels in the NAcc than ibogaine, which correlates with the ability of both compounds to inhibit SERT in vitro ( $\mathrm{IC}_{50}$ of 3.85 and $0.18 \mu \mathrm{M}$ for ibogaine and noribogaine, respectively) (Baumann et al., 2001). In this manner, a sustained enhancement on serotonin transmission due to ibogaine and its longlasting metabolite noribogaine could account, at least in part, for the observed effect on BDNF and GDNF expression after $24 \mathrm{~h}$ of ibogaine administration.

Finally, in addition to GDNF and BDNF, ibogaine also modulated the expression of NGF $24 \mathrm{~h}$ after treatment, while no changes were found at $3 \mathrm{~h}$. The effect of NGF administration in specific brain areas on drug-seeking behavior has been less studied in comparison to GDNF and BDNF, and scarce data is available on the effects of NGF in brain regions related to the dopaminergic mesocorticolimbic circuitry. Nevertheless, NGF (as other neurotrophins) is likely involved in mediating important responses related to chronic intake of drugs of abuse, as illustrated by a previous study that points to a role NGF plays in the central amygdala in the development of increased sensitivity to opioid reward (Bie et al., 2012). 
The modifications in NFs levels induced by ibogaine/noribogaine, may underlie neuroplasticity processes in the discrete brain regions analyzed as has been described by several drugs used in clinical practice including drugs of abuse (Castren and Antila, 2017). Most of these drugs regulate the expression of NFs, reactivating a process defined as induced plasticity (iPlasticity), which allows networks reorganization in the adult brain (Castren and Antila, 2017).

\subsection{Conclusions and future perspectives}

This study demonstrates for the first time that ibogaine administration simultaneously alters the expression of GDNF, BDNF and NGF in rat brain regions related to the dopamine neurotransmission in a dose and time dependent manner. Our results add relevant information concerning specific brain areas involved in the increment of GDNF levels (VTA) as a putative mechanism of action underlying the anti-addictive effect of ibogaine. In addition, we showed that only $\mathrm{I}_{40}$ promoted this increase in GDNF content, which is in accordance with previous reports where the $\mathrm{I}_{20}$ treatment was not effective in reducing drug self-administration in rodents (Glick et al., 1991; Cappendijk and Dzoljic, 1993; Glick et al., 1994; Dworkin et al., 1995). Also, we found that both doses of ibogaine produced an increase in the proBDNF content in NAcc after $24 \mathrm{~h}$ of treatment, which could be an important factor mediating ibogaine antiaddictive long-lasting effects, in addition to the already highlighted increase in GDNF. Future experiments are needed in order to clarify these important implications.

\section{Conflict of Interest}

The authors declare that the research was conducted in the absence of any commercial or financial relationships that could be considered as a potential conflict of interest.

\section{Author Contributions}

SM, BG and SR did the qPCR experiments. EM and SR performed the Western Blot experiments. SM, BG, LMP and MP contributed in the experiments and in the analysis of the data. BG prepared the ibogaine $\mathrm{HCl}$ used in this study. JPP, PR and CS, did the experiments with animals and the brain dissection. IC, PC, GS and CS provided the funding for the experiments. MP, PC, GS, CS, DS and IC planned the experiments, and wrote the manuscript. All the authors participated in critical revision the manuscript, added important intellectual content, and approved the definitive version. 


\section{Funding}

Agencia Nacional de Investigación e Innovación (ANII, Montevideo - Uruguay) Project Fondo María Viñas 103488, Comisión Sectorial de Investigación Científica (UdelaR) - Projects Grupos I+D 981 and 1104, and Programa de Desarrollo de Ciencia Básicas (PEDECIBA).

\section{Acknowledgments}

We would like to thank Agencia Nacional de Investigación e Innovación (ANII) and Comisión Sectorial de Investigación Científica (CSIC-UdelaR) for financial support. We thank Inés Carrera, Analia Richeri and Juan Pablo Rodríguez for their help in designing the manuscript figures. We also would like to thank Dr. Kenneth Alper for important discussions regarding ibogaine and noribogaine pharmacology. 


\section{References}

Aloe, L., Bracci-Laudiero, L., and Tirassa, P. (1993). The effect of chronic ethanol intake on brain NGF level and on NGF-target tissues of adult mice. Drug Alcohol Depend 31, 159-167.

Alper, K.R. (2001). "Ibogaine: A review."), 1-38.

Barde, Y.A. (1990). The nerve growth factor family. Prog Growth Factor Res 2, 237-248.

Baumann, M.H., Rothman, R.B., Pablo, J.P., and Mash, D.C. (2001). In vivo neurobiological effects of ibogaine and its O-desmethyl metabolite, 12-hydroxyibogamine (noribogaine), in rats. The Journal of pharmacology and experimental therapeutics 297, 531-539.

Benarroch, E.E. (2015). Brain-derived neurotrophic factor: Regulation, effects, and potential clinical relevance. Neurology 84, 1693-1704.

Berglind, W.J., See, R.E., Fuchs, R.A., Ghee, S.M., Whitfield, T.W., Jr., Miller, S.W., and Mcginty, J.F. (2007). A BDNF infusion into the medial prefrontal cortex suppresses cocaine seeking in rats. Eur J Neurosci 26, 757-766.

Bie, B., Wang, Y., Cai, Y.Q., Zhang, Z., Hou, Y.Y., and Pan, Z.Z. (2012). Upregulation of nerve growth factor in central amygdala increases sensitivity to opioid reward. Neuropsychopharmacology 37, 2780-2788.

Bolaños, C.A., and Nestler, E.J. (2004). Neurotrophic mechanisms in drug addiction. Neuromolecular Med 5, 69-83.

Borodinova, A.A., and Salozhin, S.V. (2016). [Diversity of proBDNF and mBDNF functions in the central nervous system]. Zh Vyssh Nerv Deiat Im I P Pavlova 66, 3-23.

Brown, T.K. (2013). Ibogaine in the treatment of substance dependence. Curr Drug Abuse Rev 6, 3-16.

Brown, T.K., and Alper, K. (2017). Treatment of opioid use disorder with ibogaine: detoxification and drug use outcomes. Am J Drug Alcohol Abuse, 1-13.

Bulling, S., Schicker, K., Zhang, Y.W., Steinkellner, T., Stockner, T., Gruber, C.W., Boehm, S., Freissmuth, M., Rudnick, G., Sitte, H.H., and Sandtner, W. (2012). The mechanistic basis for noncompetitive ibogaine inhibition of serotonin and dopamine transporters. $J$ Biol Chem 287, 18524-18534.

Burke, A.R., and Miczek, K.A. (2015). Escalation of cocaine self-administration in adulthood after social defeat of adolescent rats: role of social experience and adaptive coping behavior. Psychopharmacology (Berl) 232, 3067-3079.

Calabresi, P., Picconi, B., Tozzi, A., Ghiglieri, V., and Di Filippo, M. (2014). Direct and indirect pathways of basal ganglia: a critical reappraisal. Nat Neurosci 17, 1022-1030.

Cappendijk, S.L., and Dzoljic, M.R. (1993). Inhibitory effects of ibogaine on cocaine selfadministration in rats. Eur J Pharmacol 241, 261-265.

Carnicella, S., Ahmadiantehrani, S., Janak, P.H., and Ron, D. (2009). GDNF is an endogenous negative regulator of ethanol-mediated reward and of ethanol consumption after a period of abstinence. Alcohol Clin Exp Res 33, 1012-1024. 
Carnicella, S., He, D.Y., Yowell, Q.V., Glick, S.D., and Ron, D. (2010). Noribogaine, but not 18-MC, exhibits similar actions as ibogaine on GDNF expression and ethanol selfadministration. Addict Biol 15, 424-433.

Carnicella, S., Kharazia, V., Jeanblanc, J., Janak, P.H., and Ron, D. (2008). GDNF is a fastacting potent inhibitor of alcohol consumption and relapse. Proc Natl Acad Sci U S A 105, 8114-8119.

Carnicella, S., and Ron, D. (2009). GDNF--a potential target to treat addiction. Pharmacol Ther 122, 9-18.

Castren, E., and Antila, H. (2017). Neuronal plasticity and neurotrophic factors in drug responses. Mol Psychiatry 22, 1085-1095.

Day, M., Wokosin, D., Plotkin, J.L., Tian, X., and Surmeier, D.J. (2008). Differential excitability and modulation of striatal medium spiny neuron dendrites. $J$ Neurosci 28 , $11603-11614$.

De Sousa Abreu, R., Penalva, L.O., Marcotte, E.M., and Vogel, C. (2009). Global signatures of protein and mRNA expression levels. Mol Biosyst 5, 1512-1526.

Di Chiara, G., and Imperato, A. (1988). Drugs abused by humans preferentially increase synaptic dopamine concentrations in the mesolimbic system of freely moving rats. Proc Natl Acad Sci U S A 85, 5274-5278.

Dwivedi, Y., Rizavi, H.S., and Pandey, G.N. (2006). Antidepressants reverse corticosteronemediated decrease in brain-derived neurotrophic factor expression: differential regulation of specific exons by antidepressants and corticosterone. Neuroscience 139, 1017-1029.

Dworkin, S.I., Gleeson, S., Meloni, D., Koves, T.R., and Martin, T.J. (1995). Effects of ibogaine on responding maintained by food, cocaine and heroin reinforcement in rats. Psychopharmacology (Berl) 117, 257-261.

Dzoljic, E.D., Kaplan, C.D., and Dzoljic, M.R. (1988). Effect of ibogaine on naloxoneprecipitated withdrawal syndrome in chronic morphine-dependent rats. Arch Int Pharmacodyn Ther 294, 64-70.

Evans, S.F., Irmady, K., Ostrow, K., Kim, T., Nykjaer, A., Saftig, P., Blobel, C., and Hempstead, B.L. (2011). Neuronal brain-derived neurotrophic factor is synthesized in excess, with levels regulated by sortilin-mediated trafficking and lysosomal degradation. J Biol Chem 286, 29556-29567.

Gassaway, M.M., Jacques, T.L., Kruegel, A.C., Karpowicz, R.J., Jr., Li, X., Li, S., Myer, Y., and Sames, D. (2016). Deconstructing the Iboga Alkaloid Skeleton: Potentiation of FGF2-induced Glial Cell Line-Derived Neurotrophic Factor Release by a Novel Compound. ACS Chem Biol 11, 77-87.

Ghitza, U.E., Zhai, H., Wu, P., Airavaara, M., Shaham, Y., and Lu, L. (2010). Role of BDNF and GDNF in drug reward and relapse: a review. Neurosci Biobehav Rev 35, 157-171.

Glick, S.D., Kuehne, M.E., Raucci, J., Wilson, T.E., Larson, D., Keller, R.W., Jr., and Carlson, J.N. (1994). Effects of iboga alkaloids on morphine and cocaine self-administration in rats: relationship to tremorigenic effects and to effects on dopamine release in nucleus accumbens and striatum. Brain Res 657, 14-22. 
Glick, S.D., Maisonneuve, I.M., and Szumlinski, K.K. (2001). Mechanisms of action of ibogaine: relevance to putative therapeutic effects and development of a safer iboga alkaloid congener. Alkaloids Chem Biol 56, 39-53.

Glick, S.D., Rossman, K., Rao, N.C., Maisonneuve, I.M., and Carlson, J.N. (1992). Effects of ibogaine on acute signs of morphine withdrawal in rats: independence from tremor. Neuropharmacology 31, 497-500.

Glick, S.D., Rossman, K., Steindorf, S., Maisonneuve, I.M., and Carlson, J.N. (1991). Effects and aftereffects of ibogaine on morphine self-administration in rats. Eur J Pharmacol 195, 341-345.

Golan, M., Schreiber, G., and Avissar, S. (2011). Antidepressants elevate GDNF expression and release from C(6) glioma cells in a beta-arrestin1-dependent, CREB interactive pathway. Int $J$ Neuropsychopharmacol 14, 1289-1300.

Gonzalez, J., Prieto, J.P., Rodriguez, P., Cavelli, M., Benedetto, L., Mondino, A., Pazos, M., Seoane, G., Carrera, I., Scorza, C., and Torterolo, P. (2018). Ibogaine Acute Administration in Rats Promotes Wakefulness, Long-Lasting REM Sleep Suppression, and a Distinctive Motor Profile. Front Pharmacol 9, 374.

Graham, D.L., Edwards, S., Bachtell, R.K., Dileone, R.J., Rios, M., and Self, D.W. (2007). Dynamic BDNF activity in nucleus accumbens with cocaine use increases selfadministration and relapse. Nat Neurosci 10, 1029-1037.

He, D.-Y., Mcgough, N.N.H., Ravindranathan, A., Jeanblanc, J., Logrip, M.L., Phamluong, K., Janak, P.H., and Ron, D. (2005). Glial Cell Line-Derived Neurotrophic Factor Mediates the Desirable Actions of the Anti-Addiction Drug Ibogaine against Alcohol Consumption. The Journal of Neuroscience 25, 619-628.

He, D.-Y., and Ron, D. (2006). Autoregulation of glial cell line-derived neurotrophic factor expression: implications for the long-lasting actions of the anti-addiction drug, Ibogaine. The FASEB journal : official publication of the Federation of American Societies for Experimental Biology 20, 2420-2422.

Hisaoka, K., Nishida, A., Koda, T., Miyata, M., Zensho, H., Morinobu, S., Ohta, M., and Yamawaki, S. (2001). Antidepressant drug treatments induce glial cell line-derived neurotrophic factor (GDNF) synthesis and release in rat C6 glioblastoma cells. $J$ Neurochem 79, 25-34.

Huang, Z., Zhong, X.M., Li, Z.Y., Feng, C.R., Pan, A.J., and Mao, Q.Q. (2011). Curcumin reverses corticosterone-induced depressive-like behavior and decrease in brain BDNF levels in rats. Neurosci Lett 493, 145-148.

Jacobs, M.T., Zhang, Y.W., Campbell, S.D., and Rudnick, G. (2007). Ibogaine, a noncompetitive inhibitor of serotonin transport, acts by stabilizing the cytoplasm-facing state of the transporter. J Biol Chem 282, 29441-29447.

Jenks, C.W. (2002). Extraction studies of Tabernanthe iboga and Voacanga africana. Nat Prod Lett 16, 71-76.

Kalivas, P.W., and Volkow, N.D. (2005). The neural basis of addiction: a pathology of motivation and choice. Am J Psychiatry 162, 1403-1413.

Koenig, X., and Hilber, K. (2015). The anti-addiction drug ibogaine and the heart: a delicate relation. Molecules 20, 2208-2228. 
Koob, G.F., and Bloom, F.E. (1988). Cellular and molecular mechanisms of drug dependence. Science 242, 715-723.

Koskela, M., Back, S., Voikar, V., Richie, C.T., Domanskyi, A., Harvey, B.K., and Airavaara, M. (2017). Update of neurotrophic factors in neurobiology of addiction and future directions. Neurobiol Dis 97, 189-200.

Krishnan, V., Han, M.H., Graham, D.L., Berton, O., Renthal, W., Russo, S.J., Laplant, Q., Graham, A., Lutter, M., Lagace, D.C., Ghose, S., Reister, R., Tannous, P., Green, T.A., Neve, R.L., Chakravarty, S., Kumar, A., Eisch, A.J., Self, D.W., Lee, F.S., Tamminga, C.A., Cooper, D.C., Gershenfeld, H.K., and Nestler, E.J. (2007). Molecular adaptations underlying susceptibility and resistance to social defeat in brain reward regions. Cell 131, 391-404.

Lavaud, C., and Massiot, G. (2017). The Iboga Alkaloids. Prog Chem Org Nat Prod 105, 89136.

Leal, M.B., Michelin, K., Souza, D.O., and Elisabetsky, E. (2003). Ibogaine attenuation of morphine withdrawal in mice: role of glutamate N-methyl-D-aspartate receptors. Prog Neuropsychopharmacol Biol Psychiatry 27, 781-785.

Lu, B., and Figurov, A. (1997). Role of neurotrophins in synapse development and plasticity. Rev Neurosci 8, 1-12.

Lu, L., Dempsey, J., Liu, S.Y., Bossert, J.M., and Shaham, Y. (2004). A single infusion of brain-derived neurotrophic factor into the ventral tegmental area induces long-lasting potentiation of cocaine seeking after withdrawal. J Neurosci 24, 1604-1611.

Maciulaitis, R., Kontrimaviciute, V., Bressolle, F.M., and Briedis, V. (2008). Ibogaine, an antiaddictive drug: pharmacology and time to go further in development. A narrative review. Hum Exp Toxicol 27, 181-194.

Maier, T., Guell, M., and Serrano, L. (2009). Correlation of mRNA and protein in complex biological samples. FEBS Lett 583, 3966-3973.

Meikle, M.N., Prieto, J.P., Urbanavicius, J., Lopez, X., Abin-Carriquiry, J.A., Prunell, G., and Scorza, M.C. (2013). Anti-aggressive effect elicited by coca-paste in isolation-induced aggression of male rats: influence of accumbal dopamine and cortical serotonin. Pharmacol Biochem Behav 110, 216-223.

Mercier, G., Lennon, A.M., Renouf, B., Dessouroux, A., Ramauge, M., Courtin, F., and Pierre, M. (2004). MAP kinase activation by fluoxetine and its relation to gene expression in cultured rat astrocytes. J Mol Neurosci 24, 207-216.

Messer, C.J., Eisch, A.J., Carlezon, W.A., Whisler, K., Shen, L., Wolf, D.H., Westphal, H., Collins, F., and Russell, D.S. (2000). Role for GDNF in Biochemical and Behavioral Adaptations to Drugs of Abuse. Neuron 26.

Montagud-Romero, S., Nunez, C., Blanco-Gandia, M.C., Martinez-Laorden, E., Aguilar, M.A., Navarro-Zaragoza, J., Almela, P., Milanes, M.V., Laorden, M.L., Minarro, J., and Rodriguez-Arias, M. (2017). Repeated social defeat and the rewarding effects of cocaine in adult and adolescent mice: dopamine transcription factors, proBDNF signaling pathways, and the TrkB receptor in the mesolimbic system. Psychopharmacology (Berl) 234, 2063-2075. 
Moretto, G., Walker, D., Lanteri, P., Taioli, F., Zaffagnini, S., Xu, R., and Rizzuto, N. (1996). Expression and regulation of glial-cell-line-derived neurotrophic factor (GDNF) mRNA in human astrocytes in vitro. Cell Tissue Res 286, 257-262.

Noller, G.E., Frampton, C.M., and Yazar-Klosinski, B. (2017). Ibogaine treatment outcomes for opioid dependence from a twelve-month follow-up observational study. Am J Drug Alcohol Abuse, 1-10.

Paxinos, G., and Watson, C. (2005). The Rat Brain in Stereotaxic Coordinates. Sydney: Academic Press.

Pearl, S.M., Hough, L.B., Boyd, D.L., and Glick, S.D. (1997). Sex differences in ibogaine antagonism of morphine-induced locomotor activity and in ibogaine brain levels and metabolism. Pharmacol Biochem Behav 57, 809-815.

Pochon, N.A., Menoud, A., Tseng, J.L., Zurn, A.D., and Aebischer, P. (1997). Neuronal GDNF expression in the adult rat nervous system identified by in situ hybridization. Eur $J$ Neurosci 9, 463-471.

Popova, N.K., Ilchibaeva, T.V., and Naumenko, V.S. (2017). Neurotrophic Factors (BDNF and GDNF) and the Serotonergic System of the Brain. Biochemistry (Mosc) 82, 308-317.

Rantamaki, T., Hendolin, P., Kankaanpaa, A., Mijatovic, J., Piepponen, P., Domenici, E., Chao, M.V., Mannisto, P.T., and Castren, E. (2007). Pharmacologically diverse antidepressants rapidly activate brain-derived neurotrophic factor receptor TrkB and induce phospholipase-Cgamma signaling pathways in mouse brain. Neuropsychopharmacology 32, 2152-2162.

Reichardt, L.F. (2006). Neurotrophin-regulated signalling pathways. Philos Trans $R$ Soc Lond B Biol Sci 361, 1545-1564.

Russo, S.J., Mazei-Robison, M.S., Ables, J.L., and Nestler, E.J. (2009). Neurotrophic factors and structural plasticity in addiction. Neuropharmacology 56 Suppl 1, 73-82.

Scorza, M.C., Carrau, C., Silveira, R., Zapata-Torres, G., Cassels, B.K., and Reyes-Parada, M. (1997). Monoamine oxidase inhibitory properties of some methoxylated and alkylthio amphetamine derivatives: structure-activity relationships. Biochem Pharmacol 54, 1361-1369.

Schaar, D.G., Sieber, B.A., Dreyfus, C.F., and Black, I.B. (1993). Regional and cell-specific expression of GDNF in rat brain. Exp Neurol 124, 368-371.

Schenberg, E.E., De Castro Comis, M.A., Chaves, B.R., and Da Silveira, D.X. (2014). Treating drug dependence with the aid of ibogaine: a retrospective study. $J$ Psychopharmacol 28, 993-1000.

Schmidt, H.D., and Duman, R.S. (2007). The role of neurotrophic factors in adult hippocampal neurogenesis, antidepressant treatments and animal models of depressive-like behavior. Behav Pharmacol 18, 391-418.

Shadfar, S., Kim, Y.G., Katila, N., Neupane, S., Ojha, U., Bhurtel, S., Srivastav, S., Jeong, G.S., Park, P.H., Hong, J.T., and Choi, D.Y. (2018). Neuroprotective Effects of Antidepressants via Upregulation of Neurotrophic Factors in the MPTP Model of Parkinson's Disease. Mol Neurobiol 55, 554-566.

Shirayama, Y., Yang, C., Zhang, J.C., Ren, Q., Yao, W., and Hashimoto, K. (2015). Alterations in brain-derived neurotrophic factor (BDNF) and its precursor proBDNF in the brain 
regions of a learned helplessness rat model and the antidepressant effects of a TrkB agonist and antagonist. Eur Neuropsychopharmacol 25, 2449-2458.

Sun, Y., Lim, Y., Li, F., Liu, S., Lu, J.J., Haberberger, R., Zhong, J.H., and Zhou, X.F. (2012). ProBDNF collapses neurite outgrowth of primary neurons by activating RhoA. PLoS One 7, e35883.

Tsuchioka, M., Takebayashi, M., Hisaoka, K., Maeda, N., and Nakata, Y. (2008). Serotonin (5-HT) induces glial cell line-derived neurotrophic factor (GDNF) mRNA expression via the transactivation of fibroblast growth factor receptor 2 (FGFR2) in rat C6 glioma cells. J Neurochem 106, 244-257.

Wei, D., Maisonneuve, I.M., Kuehne, M.E., and Glick, S.D. (1998). Acute iboga alkaloid effects on extracellular serotonin (5-HT) levels in nucleus accumbens and striatum in rats. Brain Res 800, 260-268.

Wells, G.B., Lopez, M.C., and Tanaka, J.C. (1999). The effects of ibogaine on dopamine and serotonin transport in rat brain synaptosomes. Brain Res Bull 48, 641-647.

Woo, N.H., Teng, H.K., Siao, C.J., Chiaruttini, C., Pang, P.T., Milner, T.A., Hempstead, B.L., and Lu, B. (2005). Activation of p75NTR by proBDNF facilitates hippocampal longterm depression. Nat Neurosci 8, 1069-1077.

Xu, Z.Q., Sun, Y., Li, H.Y., Lim, Y., Zhong, J.H., and Zhou, X.F. (2011). Endogenous proBDNF is a negative regulator of migration of cerebellar granule cells in neonatal mice. Eur J Neurosci 33, 1376-1384.

Yang, B., Yang, C., Ren, Q., Zhang, J.C., Chen, Q.X., Shirayama, Y., and Hashimoto, K. (2016). Regional differences in the expression of brain-derived neurotrophic factor (BDNF) pro-peptide, proBDNF and preproBDNF in the brain confer stress resilience. Eur Arch Psychiatry Clin Neurosci 266, 765-769.

Yang, J.W., Ma, W., Yang, Y.L., Wang, X.B., Li, X.T., Wang, T.T., Wang, X.P., Gao, W., Li, J.Y., Zhou, X.F., Guo, J.H., and Li, L.Y. (2017). Region-specific expression of precursor and mature brain-derived neurotrophic factors after chronic alcohol exposure. Am J Drug Alcohol Abuse 43, 602-608. 
Supplementary Material

\title{
Ibogaine modifies GDNF, BDNF and NGF expression in brain regions
} involved in mesocorticolimbic and nigral dopaminergic circuits

\author{
Soledad Marton ${ }^{1 \dagger}$, Bruno González ${ }^{2 \dagger}$, Sebastián Rodríguez ${ }^{1}$, Ernesto Miquel ${ }^{1}$, Laura Martínez \\ Palma $^{1}$, Mariana Pazos ${ }^{2}$, José Pedro Prieto ${ }^{3}$, Paola Rodríguez ${ }^{2}$, Dalibor Sames ${ }^{4}$, Gustavo Seoane ${ }^{2}$, \\ Cecilia Scorza $^{3^{*}}$, Patricia Cassina ${ }^{1^{*}}$, Ignacio Carrera ${ }^{2^{*}}$ \\ *Correspondence: Cecilia Scorza (cscorza@iibce.edu.uy), Patricia Cassina (pcassina@fmed.edu.uy), \\ Ignacio Carrera (icarrera@fq.edu.uy)
}

\section{Supplementary Data}

Ibogaine-HCl Preparation. Nuclear Magnetic Resonance spectra were obtained on a Bruker Avance DPX-400 instrument.

Voacangine (12-methoxy-16-carbomethoxyibogamine) isolated from Voacanga Africana root bark (see Material and Methods section in the manuscript)

${ }^{1} \mathbf{H}$ NMR $\left(400 \mathrm{MHz}, \mathrm{CDCl}_{3}\right) \delta 7.81(\mathrm{~s}, 1 \mathrm{H}), 7.13(\mathrm{~d}, J=8.7 \mathrm{~Hz}, 1 \mathrm{H}), 6.93(\mathrm{~d}, J=2.3 \mathrm{~Hz}, 1 \mathrm{H}), 6.80(\mathrm{dd}, \mathrm{J}=8.7$, $2.4 \mathrm{~Hz}, 1 \mathrm{H}), 3.84(\mathrm{~s}, 3 \mathrm{H}), 3.70(\mathrm{~s}, 3 \mathrm{H}), 3.55(\mathrm{~s}, 1 \mathrm{H}), 3.44-3.33(\mathrm{~m}, 1 \mathrm{H}), 3.26-3.08(\mathrm{~m}, 2 \mathrm{H}), 3.03-2.86(\mathrm{~m}$, $2 \mathrm{H}), 2.81(\mathrm{~d}, J=8.5 \mathrm{~Hz}, 1 \mathrm{H}), 2.58(\mathrm{dd}, J=11.8,2.1 \mathrm{~Hz}, 1 \mathrm{H}), 1.94-1.81(\mathrm{~m}, 2 \mathrm{H}), 1.73(\mathrm{t}, J=11.1 \mathrm{~Hz}, 1 \mathrm{H}), 1.56$ $(\mathrm{dt}, J=22.0,7.4 \mathrm{~Hz}, 1 \mathrm{H}), 1.49-1.39(\mathrm{~m}, 1 \mathrm{H}), 1.37-1.28(\mathrm{~m}, 2 \mathrm{H}), 1.15-1.08(\mathrm{~m}, 1 \mathrm{H}), 0.90(\mathrm{t}, J=7.3 \mathrm{~Hz}, 3 \mathrm{H})$. ${ }^{13}$ C NMR $\left(100 \mathrm{MHz}, \mathrm{CDCl}_{3}\right) \delta 175.71,153.98,137.51,130.53,129.19,116.62,111.81,111.07,110.12,100.77$, $99.99,77.34,77.03,76.71,57.52,56.04,55.14,53.13,52.59,51.52,39.15,36.56,32.03,27.35,26.76,22.22$, 11.68 .

Ibogaine $\cdot \mathbf{H C l}$ prepared by decarboxylation of voacangine (see Material and Methods section in the manuscript) ${ }^{1}$ H NMR $\left(400 \mathrm{MHz}, \mathrm{CD}_{3} \mathrm{OD}\right) \delta(\mathrm{ppm})=7.19(\mathrm{~d}, J=8.9 \mathrm{~Hz}, 1 \mathrm{H}), 6.97(\mathrm{~d}, J=2.4 \mathrm{~Hz}, 1 \mathrm{H}), 6.76(\mathrm{dd}, J=8.8,2.5$ $\mathrm{Hz}, 1 \mathrm{H}), 3.87(\mathrm{~s}, 3 \mathrm{H}), 3.70(\mathrm{dt}, J=13.4,4.2 \mathrm{~Hz}, 1 \mathrm{H}), 3.63-3.53(\mathrm{~m}, 2 \mathrm{H}), 3.45-3.34(\mathrm{~m}, 3 \mathrm{H}), 3.31-3.14(\mathrm{~m}$, 2H), 2.32 (ddt, 13.5, 12.1, 2.7 Hz, 1H), $2.19-2.09$ (m, 2H), 2.06 (hept, $J=7.5 \mathrm{~Hz}, 1 \mathrm{H}), 1.74-1.65$ (m, $3 \mathrm{H}), 1.46$ $-1.34(\mathrm{~m}, 1 \mathrm{H}), 1.03(\mathrm{t}, J=7.3 \mathrm{~Hz}, 3 \mathrm{H}){ }^{13} \mathbf{C}$ NMR $\left(100 \mathrm{MHz}, \mathrm{CD}_{3} \mathrm{OD}\right) \delta(\mathrm{ppm})=153.0,139.1,130.4,128.5$, $111.2,111.1,106.0,99.5,60.1,56.0,54.9,50.5,39.0,35.1,31.2,28.8,26.0,23.9,18,0,10.5$

To determine ibogaine- $\mathrm{HCl}$ purity (after crystallization and purification procedures described in the Materials and Methods section of the manuscript) Gas Chromatography analysis was carried out in a GC-MS Shimadzu QP $1100 \mathrm{EX}$ instrument using the electron impact mode, $70 \mathrm{eV}$. For analysis sample was previously dissolved in aqueous $\mathrm{NaOH} \mathrm{10 \%}$ and extracted with Ethyl Acetate. Conditions: Column HP-5MS (30m x 0.25mm x 0.25um) Temperature Program $200{ }^{\circ} \mathrm{C}$ (Hold time, 2 minutes) to $300{ }^{\circ} \mathrm{C}$ (Hold time, 5 minutes) with a rate of $10{ }^{\circ} \mathrm{C} / \mathrm{min}$. Ibogaine purity was determined as $98.3 \%$ (See chromatogram below) 


\section{Supplementary Figures and Tables}

\section{Supplementary Figures}

Supplementary Figure 1. Ibogaine-HCl GC-MS chromatogram.
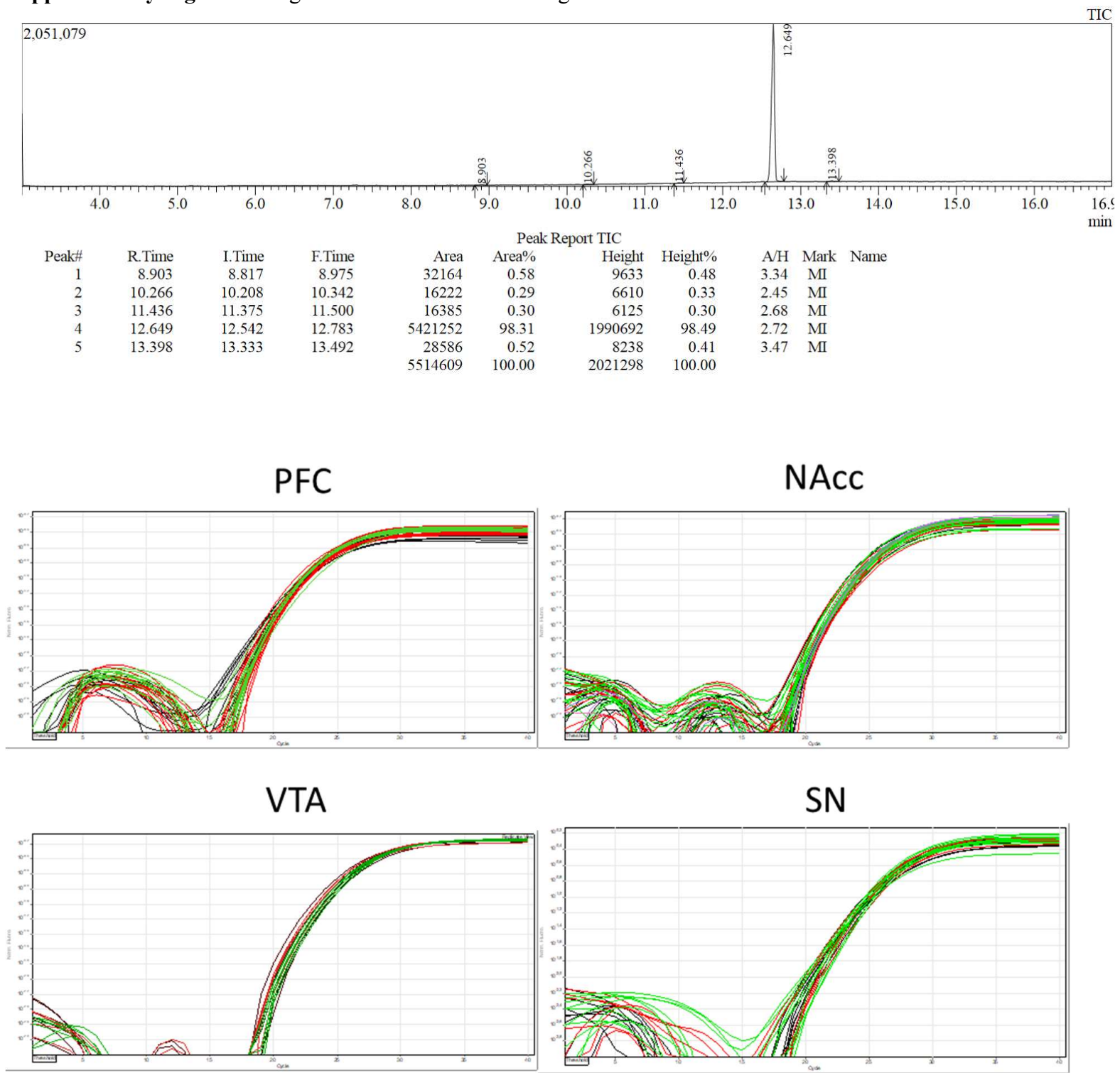

SN

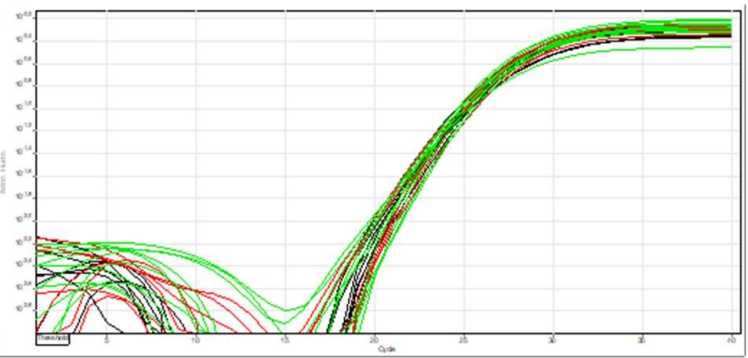

Supplementary Figure 2. PCR amplification curves showing the raw data of BDNF mRNAs at 3 hours after ibogaine administration. Norm fluorescence vs amplification cycle. Black vehicle, red $20 \mathrm{mg}$ Ibogaine, green 40 mg Ibogaine. 

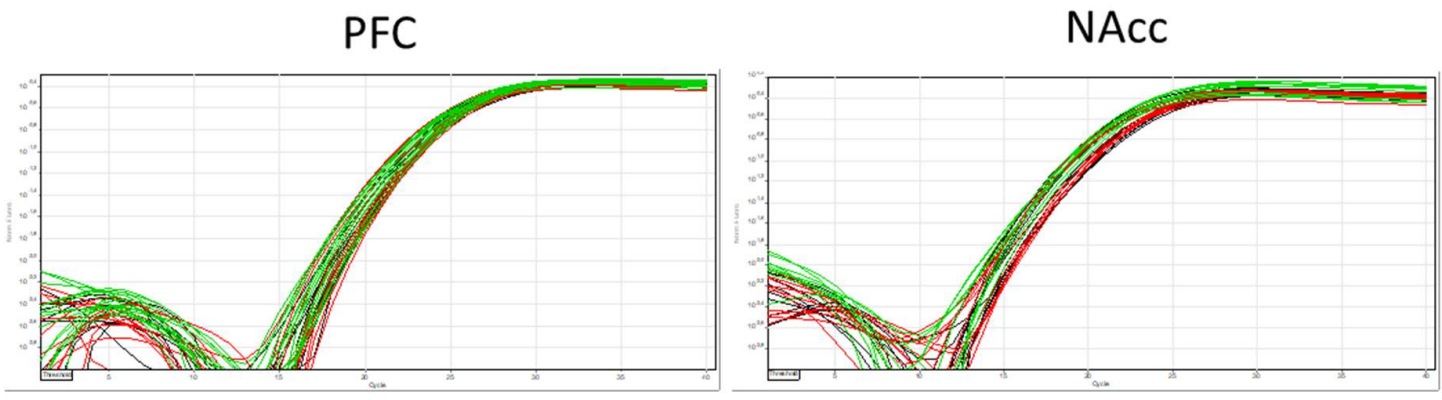

VTA
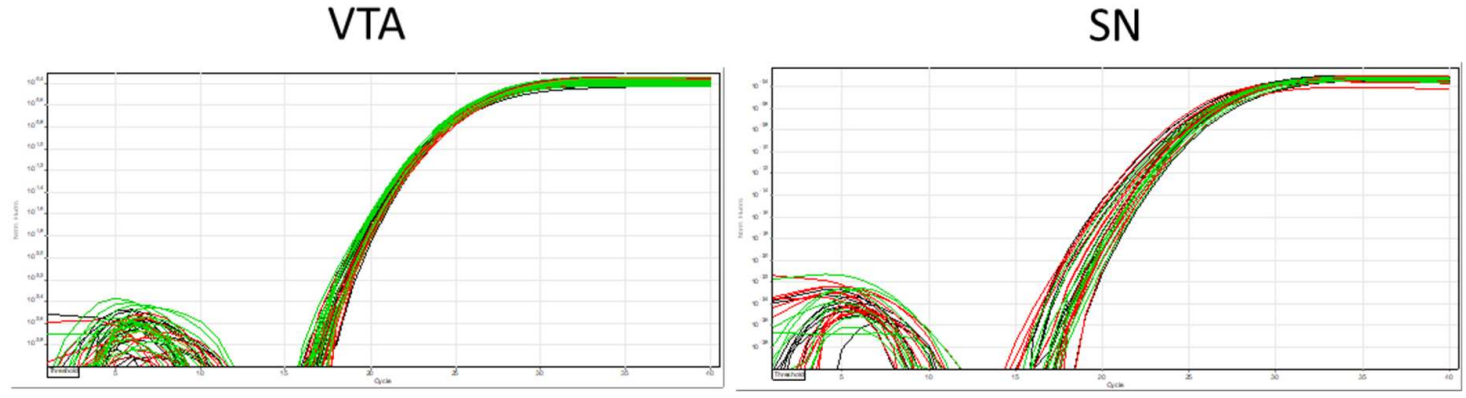

Supplementary Figure 3. PCR amplification curves showing the raw data of GDNF mRNAs at 3 hours after ibogaine administration. Norm fluorescence vs amplification cycle. Black vehicle, red $20 \mathrm{mg}$ Ibogaine, green 40 mg Ibogaine.

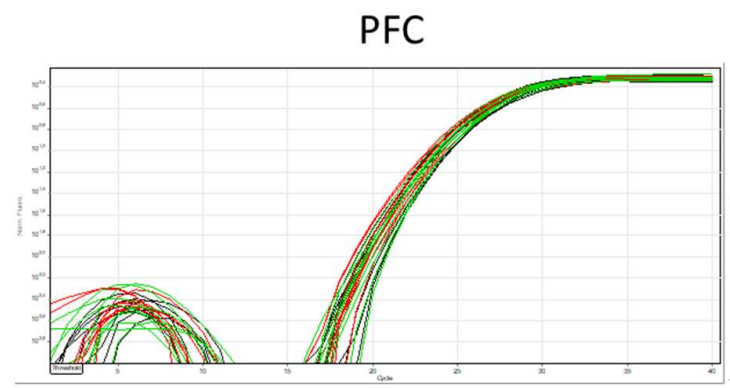

VTA

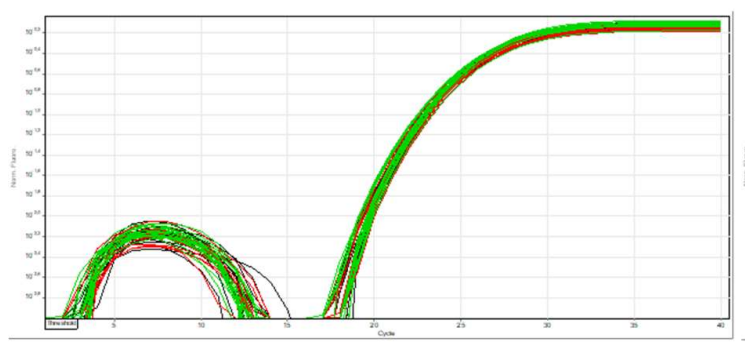

NAcC

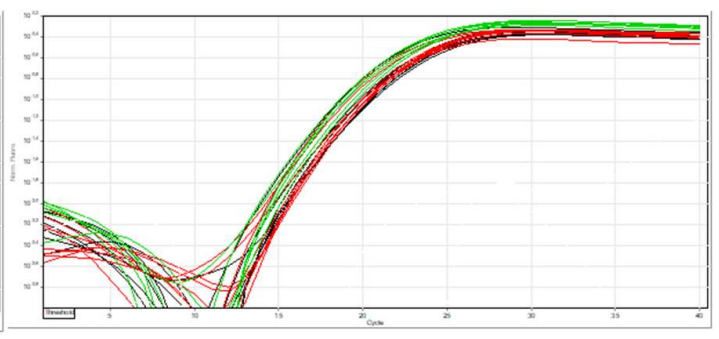

SN

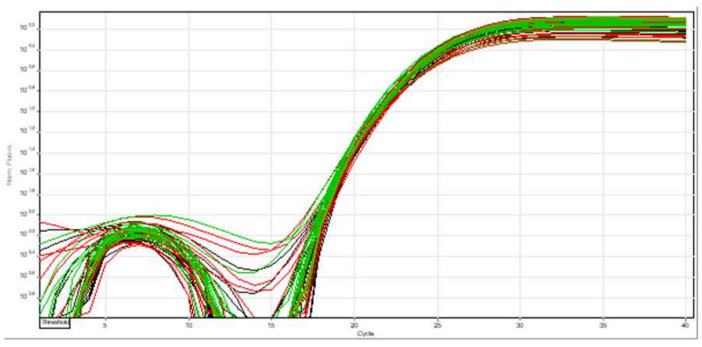

Supplementary Figure 4. PCR amplification curves showing the raw data of NGF mRNAs at 3 hours after ibogaine administration. Norm fluorescence vs amplification cycle. Black vehicle, red $20 \mathrm{mg}$ Ibogaine, green 40 mg Ibogaine. 


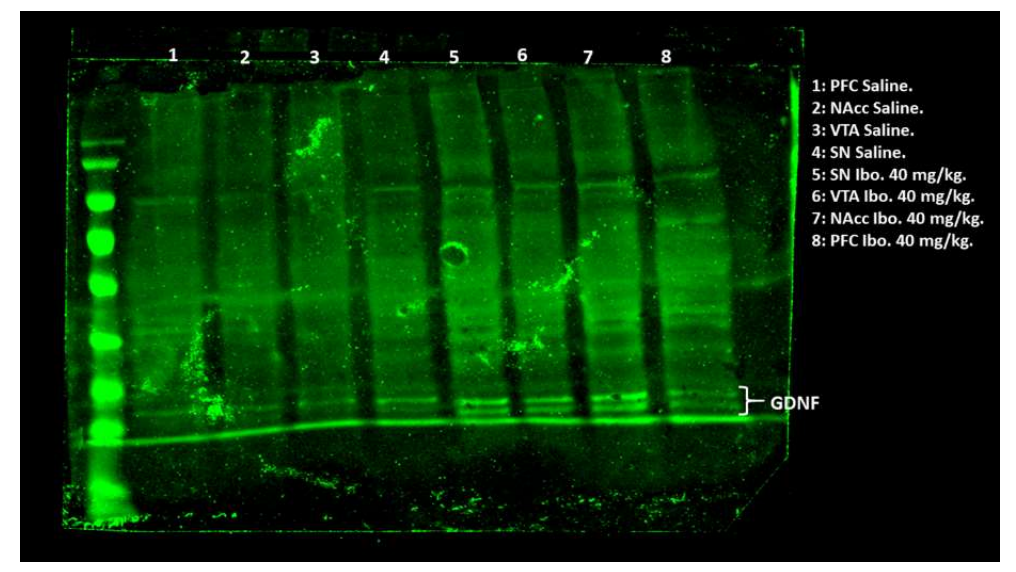

Supplementary Figure 5. Nitrocelulose membrane incubated with GDNF antibody, for Saline and Ibogaine 40 $\mathrm{mg} / \mathrm{kg}$ samples.

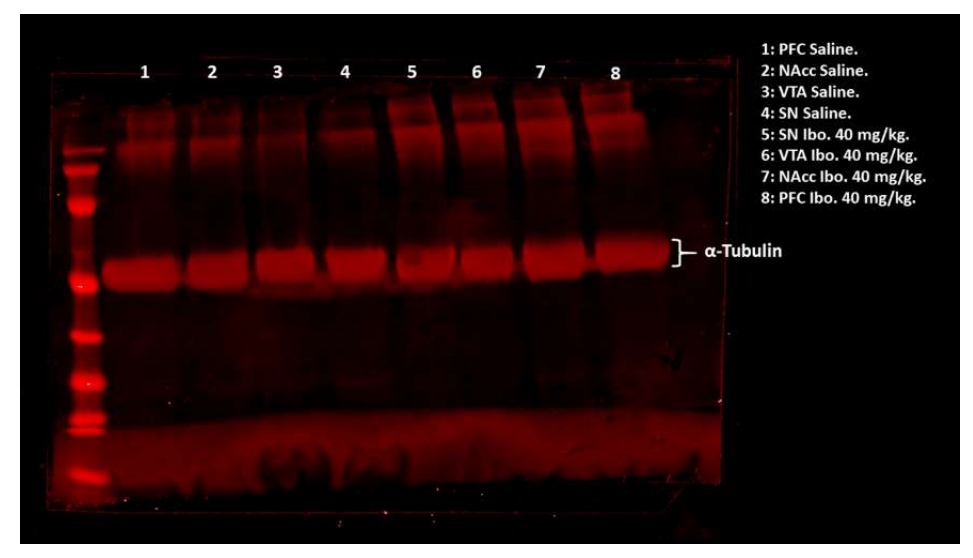

Supplementary Figure 6. Nitrocelulose membrane incubated with alpha-tubulin antibody, for Saline and Ibogaine $40 \mathrm{mg} / \mathrm{kg}$ samples.

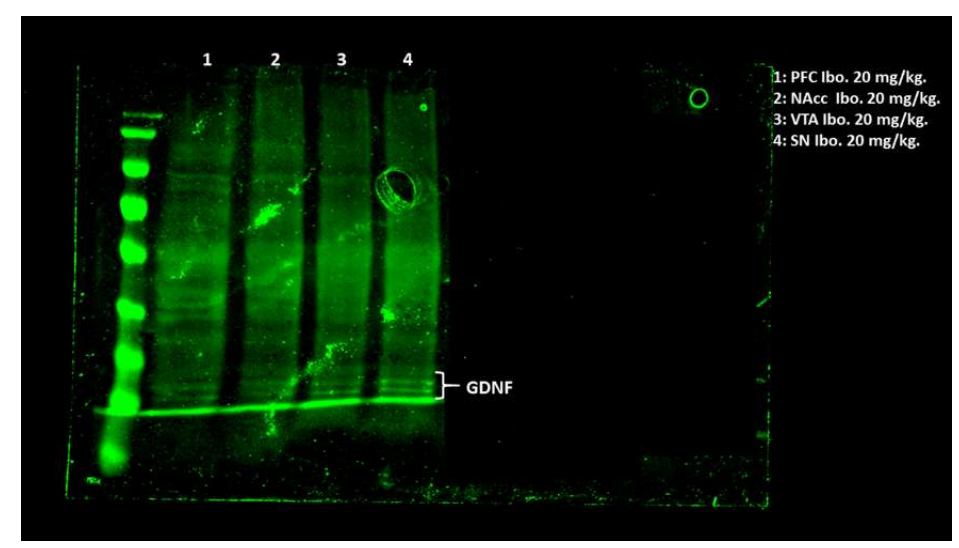

Supplementary Figure 7. Nitrocelulose membrane incubated with GDNF antibody, for Ibogaine $20 \mathrm{mg} / \mathrm{kg}$ samples. 


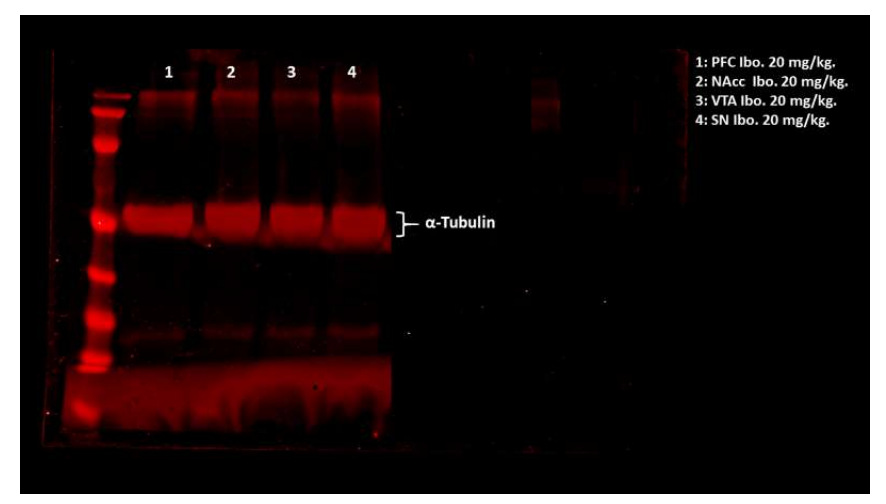

Supplementary Figure 8. Nitrocelulose membrane incubated with alpha-tubulin antibody, for Ibogaine 20 $\mathrm{mg} / \mathrm{kg}$ samples.

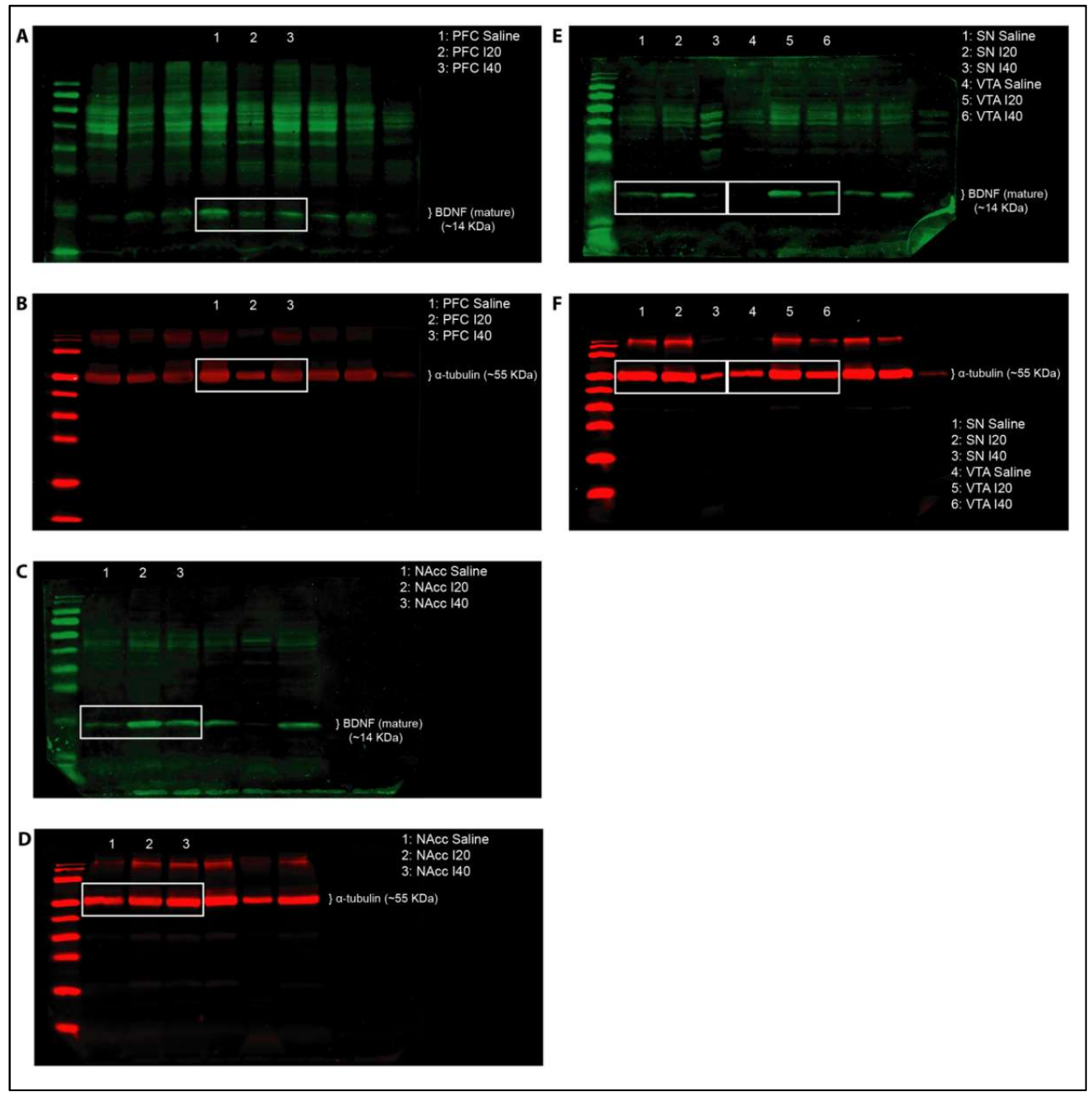

Supplementary Figure 9. Full-scanned images of western blots in main Figure 7-C. Nitrocellulose membranes corresponding to samples of PFC (A-B), NAcc (C-D), VTA and SN (E-F) from saline, I20 and I40-treated rats incubated with antibodies to $\operatorname{BDNF}(\mathbf{A}, \mathbf{C}, \mathbf{E})$ and a-tubulin $(\mathbf{B}, \mathbf{D}, \mathbf{F})$. 


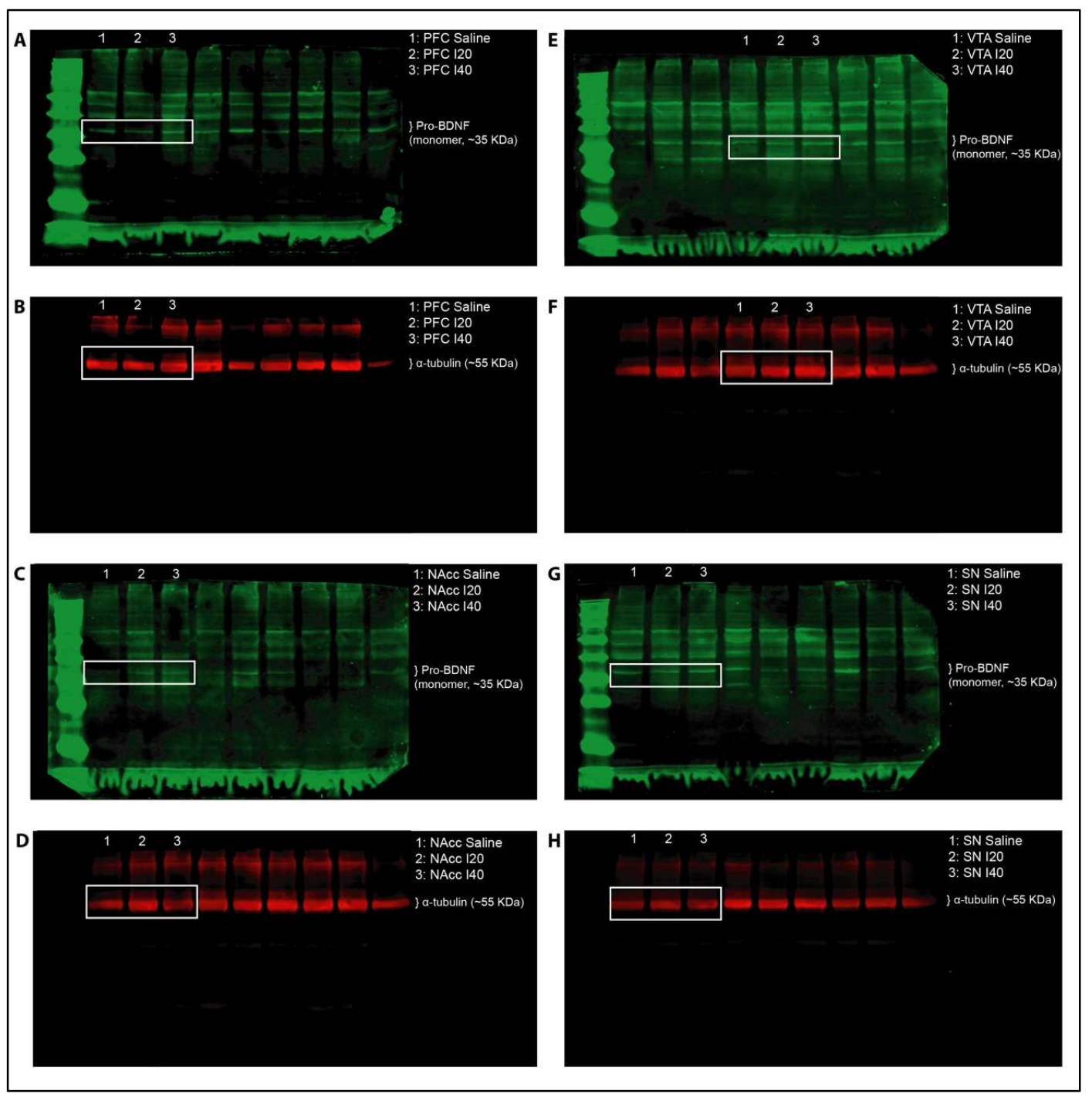

Supplementary Figure 10. Full-scanned images of western blots in main Figure 7-E. Nitrocellulose membranes corresponding to samples of PFC (A-B), NAcc (C-D), VTA (E-F) and SN (G-H) from saline, I20 and I40-treated rats incubated with antibodies to ProBDNF (A, C, E, G) and a-tubulin $(\mathbf{B}, \mathbf{D}, \mathbf{F}, \mathbf{H})$. 